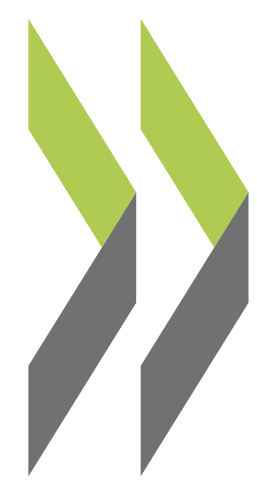

OECD Working Papers on Sovereign Borrowing and Public Debt Management No. 8

The role of public debt managers in contingent Lerzan Ülgentürk liability management 


\title{
OECD WORKING PAPERS ON SOVEREIGN BORROWING AND PUBLIC DEBT MANAGEMENT
}

\begin{abstract}
OECD Working Papers should not be reported as representing the official views of the OECD or of its member countries. The opinions expressed and arguments employed are those of the authors.

Working Papers describe preliminary results or research in progress by the author(s) and are published to stimulate discussion on a broad range of issues on which the OECD works. Comments on Working Papers are welcomed, and may be sent to Publicdebt@oecd.org or the Financial Affairs Division, Directorate for Financial and Enterprise Affairs, OECD, 2 rue André-Pascal, 75775 Paris Cedex 16, France.
\end{abstract}

OECD Working Papers on Sovereign Borrowing and Public Debt Management provide authoritative information on technical and policy issues in the area of public debt management (PDM) and government securities markets. Studies closely track structural issues, trends and challenges in government debt policies and markets.

These studies are prepared for dissemination among sovereign debt managers, financial policy makers, regulators, financial market participants, rating agencies, and academics. By providing information on this highly specialised field of government activity and policy, the papers aim to stimulate discussions among a wider audience as well as further analysis.

\section{OECD WORKING PAPERS ON SOVEREIGN BORROWING AND PUBLIC DEBT MANAGEMENT are published on http://oecd/pdmwp}

This document and any map included herein are without prejudice to the status of or sovereignty over any territory, to the delimitation of international frontiers and boundaries and to the name of any territory, city or area.

The statistical data for Israel are supplied by and under the responsibility of the relevant Israeli authorities. The use of such data by the OECD is without prejudice to the status of the Golan Heights, East Jerusalem and Israeli settlements in the West Bank under the terms of international law.

\section{(C) OECD 2017}

You can copy, download or print OECD content for your own use, and you can include excerpts from OECD publications, databases and multimedia products in your own documents, presentations, blogs, websites and teaching materials, provided that suitable acknowledgment of OECD as source and copyright owner is given. All requests for commercial use and translation rights should be submitted to rights@oecd.org. 


\title{
The role of public debt managers in contingent liability management
}

\author{
by \\ Lerzan Ülgentürk and members of the OECD Task Force on Contingent \\ Liabilities and Public Debt Management*
}

\begin{abstract}
Contingent liabilities are major sources of fiscal risks due to the uncertain financial commitments they involve. Their effective management, therefore, is essential for increasing stability and predictability in public finance.

This paper explores the role of public debt managers in contingent liability management based on the results of a background OECD survey and the information provided by seven task force countries. The results indicate that there are certain roles and responsibilities assumed by the public debt managers in this field, while the degree of involvement differs widely across countries. We also observed that the debt management offices' (DMOs) involvement is more prominent in the management of government credit guarantees, while contingent liabilities arising from Public Private Partnerships (PPPs) and government sponsored insurance programmes appear to be outside the domain of public debt managers in most cases. Drawing on leading country practices and lessons from the past, this paper advises public debt managers on possible motives and areas of involvement.
\end{abstract}

Authorised for release by Pierre Poret,

Director, OECD Directorate for Financial and Enterprise Affairs

JEL Classification: G18, H63, H81

Keywords: contingent liabilities, fiscal risk, government credit guarantees, public private partnerships, government insurance programmes, public debt management.

*Lerzan Ülgentürk is a senior expert at the Turkish Treasury designated as the project's consultant by the task force. Mmembers of the OECD task force are: Taşkın Temiz (Task Force Chair) and Fatih Kuz from the Turkish Treasury; Jose Franco Medeiros de Morais André Proite, Giovana Leivas Craveiro and Luiz Fernando Alves from the National Treasury of Brazil; Claus Johansen, Jacob Stæhr Wellendorph Ejsing and Nicolaj Hamann Christensen from Danmarks Nationalbank; Hákon Zimsen and Hafsteinn Hafsteinsson, from the Central Bank of Iceland; Jesus Ramiro Del Valle Rodriguez and Alejandro Diaz de Leon Carrillo from the Mexican Treasury; Mkhulu Maseko and Anthony Julies from the South African Treasury; Kritoffer Ekström and Eva Cassel from the Swedish National Debt Office (SNDO). The views expressed in this paper are those of the authors and do not necessarily reflect the views of the institutions for which they work. 


\section{ACKNOWLEDGEMENTS}

This paper is an output of the "Contingent Liabilities and Public Debt Management Project" initiated under the OECD Working Party on Debt Management (WPDM). Taşkın Temiz, the Task Force Chair on behalf of Turkey, mobilised the efforts of task force countries and ensured that the Turkish Treasury extended its full institutional support to the project. A team of experts from the OECD secretariat and task force countries was involved in the project. Prof. Hans J. Blommestein, former Head of the Bond Market and Public Debt Management Unit, supervised the project for two years; he coordinated work on the 2013 survey and worked closely with task force members. His successor, Fatoş Koç supported the work throughout the publication process in addition to contributing valuable comments and thoughts. Perla Ibarlucea Flores (OECD) and Hakan Bingöl (Turkish Treasury) compiled the survey results, and coordinated communication between task force countries. The authors are grateful to Mehmet Emre Elmadağ, Mustafa Burak Şener and Tuğba İldaş from the Turkish Treasury who contributed comments and support. 


\section{TABLE OF CONTENTS}

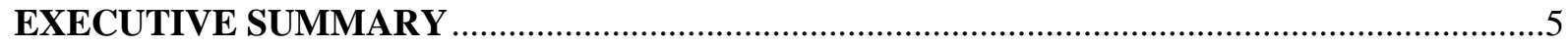

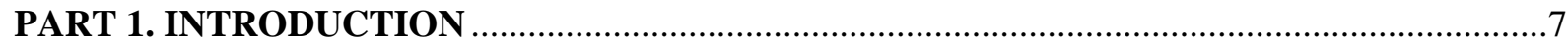

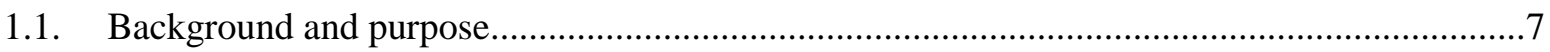

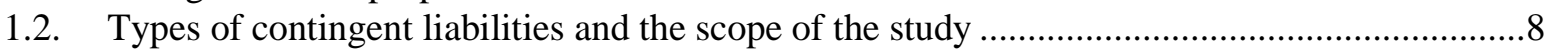



PART 2. THE ROLE OF PUBLIC DEBT MANAGERS

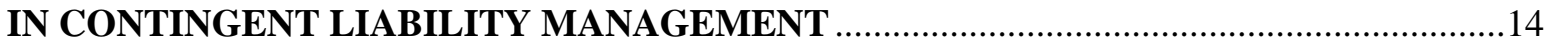

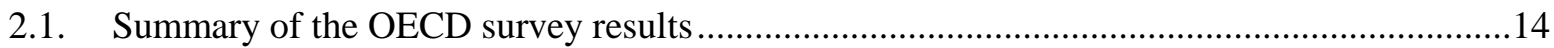

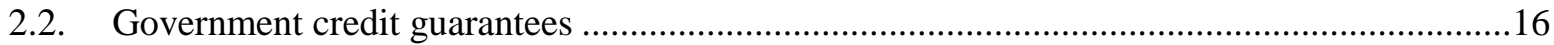



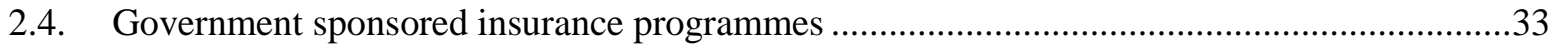

PART 3. SUMMARY OF POLICY CONCLUSIONS AND RECOMMENDATIONS ................40

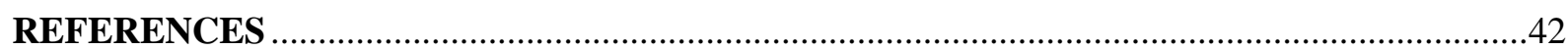

\section{Tables}

Table 1. Direct and contingent liabilities of central government ...................................................... 9

Table 2. DMOs' involvement in management of different types of contingent liabilities .................... 15

Table 3. Types of roles DMOs play in different areas of contingent liability management ${ }^{(*)} \ldots \ldots \ldots \ldots . . . .15$

Table 4. Examples of credit guarantee issuance frameworks............................................................... 19



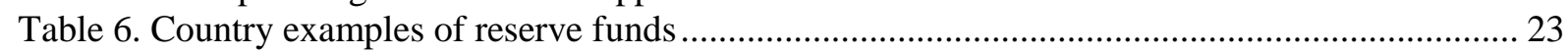

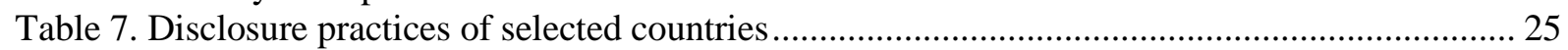

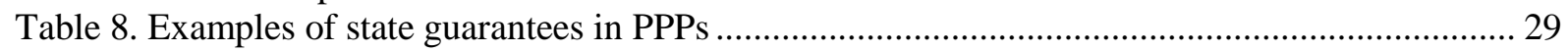



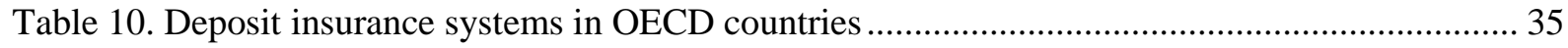

Table 11. Roles of government in disaster insurance schemes and country examples ......................... 38

\section{Figures}

Figure 1. Central government marketable gross debt in OECD countries .......................................... 11

Figure 2. Gross issuance of bank bonds in the euro area, the UK and the US .................................. 12

Figure 3. Level of contingent liabilities in the euro area and the EU 28 (2007-2014) .......................... 13

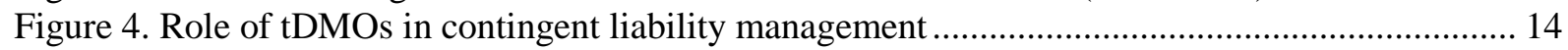

Figure 5. Effect of the global financial crisis on the role of DMOs ................................................. 16

Figure 6. European PPP market by value and number of projects ...................................................... 27 


\section{ACRONYMS AND ABBREVIATIONS}

\begin{tabular}{|c|c|}
\hline ALM & Asset and liability management \\
\hline BRL & Brazilian Real \\
\hline DKK & Danish Krone \\
\hline DMO & Debt management office \\
\hline ECA & Export credit agency \\
\hline EPEC & European Public Private Partnership Expertise Centre \\
\hline ESA & European System of Accounts \\
\hline EU & European Union \\
\hline Eurostat & Statistical Office of the European Union \\
\hline FLC & Fiscal Liabilities Committee (South Africa) \\
\hline GDP & Gross domestic product \\
\hline $\mathrm{IMF}$ & International Monetary Fund \\
\hline ISK & Icelandic Krona \\
\hline MXN & Mexican Peso \\
\hline OECD & Organisation of Economic Cooperation and Development \\
\hline PDM & Public debt management \\
\hline PPP & Public private partnership \\
\hline SEK & Swedish Krona \\
\hline SGF & State Guarantee Fund (Iceland) \\
\hline SME & Small and medium-sized enterprise \\
\hline SNA & The System of National Accounts \\
\hline SNDO & Swedish National Debt Office \\
\hline SOE & State owned enterprise \\
\hline TRL & Turkish Lira \\
\hline WB & World Bank \\
\hline WPDM & Working Party on Debt Management \\
\hline ZAR & South African Rand \\
\hline
\end{tabular}




\section{EXECUTIVE SUMMARY}

Contingent liabilities are significant sources of fiscal risks. History has shown that if governments do not effectively manage fiscal risks arising from contingent liabilities and take necessary risk management measures in a timely manner, they can be caught unprepared for their fiscal burden.

From a sovereign debt management perspective, effective management of fiscal risks arising from contingent liabilities has long been a concern because realisation of these risks has direct consequences on governments' fiscal positions and thereby public debt managers' debt and cash management policies and operations.

Our research shows that governments have increased their use of guarantees and other types of contingent liabilities since the global financial crisis; in fact, the use of such instruments was a key element of policy response to the crisis. Areas where this increase is most evident are; financial sector support; credit enhancement for infrastructure financing in traditional and PPP procurement models; and SME financing. Thus, effective management and monitoring of contingent liabilities has become more important for governments than in the past.

Against this background, this paper explores the role of public debt managers in managing explicit contingent liabilities based on country practices. To this end, we considered responses to a survey on contingent liabilities among DMOs ${ }^{1}$ of OECD countries and two non-OECD countries (Brazil and South Africa) conducted by the OECD's Bond Markets and Public Debt Management Unit in October 2013. Additionally, the paper examines task force members - Turkey (Chair), Sweden, Denmark, Iceland, Mexico, Brazil and South Africa - experiences (Annex A).

One key finding of this study shows that the degree of DMO involvement in this area varies widely across countries, as well as by types of contingent liabilities, of Debt managers' experiences are also quite diverse, stemming mainly from weight variance of different sources of contingent liabilities in task force countries, and from differences in their public financial management frameworks. However, there are similarities among countries with respect to fiscal risk management tools and methods employed for managing and mitigating risks of contingent liabilities, such as guarantee issuance guidelines, budgetary limits, contingency reserve funds, parliamentary reporting, etc. Study findings point to the more active involvement of DMOs in management of government credit guarantees compared to other sources of contingent liabilities.

The study analyses country practices in three categories of contingent liabilities from the public debt management (PDM) perspective: i) government credit guarantees, ii) contingent liabilities arising from PPPs and iii) government sponsored insurance schemes. It provides insights and recommendations to help DMOs enhance their management practices. In countries where DMOs do not have any roles and responsibilities in fiscal risk management in general and contingent liability

\footnotetext{
${ }^{1}$ Throughout this study, the term Debt Management Office (DMO) refers to the organisational unit with having the mandate of the PDM in a country, regardless of the institutional structure - autonomous agency or part of ministry of finance/treasury/central bank.
} 
management in particular, the following recommendations may be relevant for other government units.

In the area of government credit guarantees, this research builds largely upon information collected in responses to the OECD survey. The recommendations include conducting cost and risk analysis before guarantee issuance, charging fees at levels covering at least the expected costs, clearly defining and limiting the guarantees in time and scope in credit guarantee contracts, applying ceilings to promote fiscal discipline, increasing governments' ability to cover possible future losses and monitoring the overall position through contingency reserve funds, and enhancing transparency by sharing both quantitative and qualitative information.

This study suggests certain areas for more active involvement by public debt managers in the management of contingent liabilities arising from PPPs. DMOs can collaborate with the central budget authority and PPP units in data consolidation, forecasting and reporting practices on PPP contingent liabilities; or include this information in their debt reporting. The study highlights the need for a central government unit analysing PPP guarantees to inform decision-making authorities on associated costs and risks. At the portfolio level, central monitoring of contingent liabilities under PPP contracts for ensuring fiscal and debt sustainability is considered essential where public debt managers can be effectively involved. It is important to note that guarantee valuation is key for informing PPP decision making, since guarantees change the risk allocation between the public and private partner.

Under the government sponsored insurance schemes category, the study focuses on explicit contingent commitments by governments under such schemes. It recommends that clear legislative frameworks should define the scope and nature of the role of government within insurance programmes. Regular co-ordination and communication mechanisms between relevant agencies and public debt managers over fiscal risks arising from the financial system are essential for effective information sharing. 


\section{PART 1. INTRODUCTION}

\subsection{Background and purpose}

OECD best practices in the area of contingent liability management from the perspective of debt managers were formulated in 2005 with the study "Explicit Contingent Liabilities in Debt Management",2 (2005 Report). The 2005 report recommends centralisation of risk management of government debt portfolio including contingent liabilities and suggests that public debt managers are well positioned to assume this duty. The report characterises contingent liabilities as a latent form of sovereign debt, and discusses that their management might call for involvement of public debt managers.

During the $22^{\text {nd }}$ OECD Global Forum on Public Debt Management (24-25 January 2013, Paris), where the 2005 Report was distributed as a background document, there was a discussion on the policy framework for capturing, measuring and mitigating the fiscal risks arising from contingent liabilities. Delegates agreed there was a need to carry out further studies on the role of public debt managers in contingent liability management, focusing more on the implementation side to add to the analytical framework provided by the 2005 report. Delegates also suggested that new work should cover post crisis developments and PPP guarantees.

In October 2013, the OECD's Bond Markets and Public Debt Management Unit conducted a survey on contingent liabilities among DMOs of OECD countries and two non-OECD countries (Brazil and South Africa.to which 33 countries (out of 36), replied. The survey included detailed questions about management of explicit and implicit contingent liabilities. As the next step, a task force was formed, consisting of seven countries - Turkey (Chair), Sweden, Denmark, Iceland, Mexico, Brazil and South Africa, to work with the OECD on this subject area, Task force members drafted detailed and comprehensive reports (Annex A) on their contingent liability management structures and operations.

Given this background, the aim of this paper is:

i) to explore the role of public debt managers in contingent liability management, drawing on the information compiled through the OECD survey and the task force country contributions ii) provide policy conclusions and recommendations for DMOs. The paper benefits from, and builds upon, the 2005 report's analytical framework. ${ }^{3}$

\footnotetext{
${ }^{2}$ The 2005 Report was drafted by an ad hoc expert group of the OECD WPDM. Members of the expert group were: Lars Hörngren, Swedish National Debt Office (SNDO), Sweden (chairman). Jan Holmberg, State Treasury, Finland. Morten Kjærgaard, Government Debt Management, Danmarks Nationalbank, Denmark. Wojciech Rzasiecki, Ministry of Finance, Poland. Jacek Skrzynski, Ministry of Finance, Poland. Marek Szczerbak, Ministry of Finance, Poland. Magnus Thor, Swedish National Debt Office, Sweden.
}

${ }^{3}$ As this work draws on the 2005 Report, it includes several direct excerpts from it. 


\subsection{Types of contingent liabilities and the study's scope}

Various definitions of the term "contingent liability" exist in fiscal management literature. The OECD's Best Practices for Budget Transparency defines contingent liabilities as "... liabilities whose budgetary impact is dependent on future events which may or may not occur (2002: 13)". They are defined as "obligations whose timing and magnitude depend on the occurrence of some uncertain future event outside the control of the government" by Cebotari A. (2008: 5). There are also some other definitions in accounting and statistical standard manuals. ${ }^{4}$ A common feature of these definitions is the existence of "uncertainty" over the obligation in question. Uncertainty differentiates contingent liabilities from direct liabilities. Contingent liabilities become government obligations only when triggered by a pre-defined event or condition, the occurrence of which is not certain.

In literature, contingent liabilities are divided into two main groups based on the notion of "obligation": ${ }^{5}$ explicit and implicit contingent liabilities. Explicit contingent liabilities are contractual government commitments to make certain payments if a particular event occurs. The basis of these commitments can be contracts, laws, or clear policy statements. Governments issue explicit contingent liabilities in order to subsidise certain activities, (e.g. housing production, exports, and student loans) or to fill gaps in the markets that private solutions are deemed unable to cover (e.g. risks that are too large for markets to bear). The most common examples of such liabilities are government credit guarantees, explicit guarantee commitments under investment projects and government sponsored insurance programmes. Implicit contingent liabilities are political or moral obligations of the government to intervene, mostly in the event of a crisis or a natural disaster. Governments do not recognise these liabilities until a particular event occurs. While the financial system constitutes the most common source for these liabilities, it is quite common to see governments covering losses or debt obligations of sub-national governments and public corporations. Implicit contingent liabilities are difficult to assess, let alone manage in a consistent manner, precisely because of their implicit nature.

This study adopts a central government viewpoint while setting a dividing line between the two categories of contingent liabilities. Table 1 shows the categorisation of direct and contingent liabilities of different levels of government and private sector as contingent liabilities of "central government". To give an example, direct debt obligations of local governments or public corporations are implicit contingent liabilities of central government, as central government might have to cover these obligations in case of failure of these public bodies. Likewise, central governments might assume in times of crisis and disasters, non-guaranteed debt of private banks, large corporations or even households. Table 1 also shows how wide the scope of implicit contingent liabilities is for central government, as it can encompass all financial commitments of the public sector and theoretically even that of the private sector.

\footnotetext{
${ }^{4}$ The definition in the System of National Accounts (SNA) 2008 is as follows: "A contingent liability is a possible obligation that arises from past events and whose existence will be confirmed only by the occurrence or non-occurrence of one or more uncertain future events not wholly within the control of the entity." ESA 2010 defines contingent liabilities as; "Contingent assets and contingent liabilities are agreements whereby one party is obliged to provide a payment or series of payments to another unit only where certain specific conditions prevail".

${ }^{5}$ Lindwall P. (2013) provides other classifications of contingent liabilities based on magnitude/impact, probability, government influence and measurability.
} 
Table 1. Direct and contingent liabilities of central government

\begin{tabular}{lc}
\hline & $\begin{array}{c}\text { Liabilities of } \\
\text { central government }\end{array}$ \\
\hline Direct liabilities of central government & $\mathrm{DL}^{*}$ \\
Direct liabilities of state government & $\mathrm{ICL}^{* *}$ \\
Direct liabilities of local government & $\mathrm{ICL}$ \\
Direct liabilities of public corporations & $\mathrm{ICL}$ \\
Direct liabilities of private sector & $\mathrm{ICL}$ \\
Contingent liabilities of central government & $\mathrm{ECL}{ }^{* * *}$ \\
Contingent liabilities of state government & $\mathrm{ICL}$ \\
Contingent liabilities of local government & $\mathrm{ICL}$ \\
Contingent liabilities of public corporations & $\mathrm{ICL}$ \\
Contingent liabilities of private sector & $\mathrm{ICL}$ \\
\hline${ }^{*}$ Direct liabilities & \\
${ }^{* * * *}$ Explicit contingent liabilities & \\
\end{tabular}

This paper elaborates the main sources of explicit contingent liabilities ${ }^{6}$ into three sub-groups. The first group consists of government credit guarantees, which we define as liabilities based on contracts through which the government assumes the whole or part of the credit risk of a loan extended to another party. In case the borrower fails to fulfil its obligations, the lender can turn to the government as guarantor and claim payment of interest and/or principal. In this study, the term "government credit guarantee" refers to all types of guarantees covering debt service obligations of beneficiaries and, as such, includes government guarantees issued for bonds as well. ${ }^{78}$ However, this study categorised credit guarantees issued within the framework of PPP projects within a different group to be discussed subsequently. In this conceptual framework, government credit guarantees comprise:

\footnotetext{
${ }^{6}$ Selected country practices presented in Annex A include information on the experiences of task force countries with implicit contingent liabilities as well.

${ }^{7}$ The term "loan guarantees" is also widely used in the literature. Please also note that the SNA 2008 attaches a different meaning to the term "credit guarantee" referring to it as guarantees to disburse un-utilized loan amounts.
}

${ }^{8}$ The SNA 2008 categorises credit guarantees as standardised guarantees and one-off guarantees. Accordingly, "Standardised guarantees are composed of the sorts of guarantees that are issued in large numbers, usually for fairly small amounts, along identical lines. There are three parties involved in these arrangements, the debtor, the creditor and the guarantor. Either the debtor or creditor may contract with the guarantor to repay the creditor if the debtor defaults. The classic examples are export credit guarantees and student loan guarantees." "... one-off guarantees, consists of those where the loan or the security is so particular that it is not possible for the degree of risk associated with the debt to be calculated with any degree of accuracy. "Standardised guarantees are to be distinguished from one-off guarantees based on two criteria: a. They are characterised by often repeated transactions with similar features and pooling of risks; b. Guarantors are able to estimate the average loss based on available statistics by using a probability-weighted concept. One-off guarantees are, on the contrary, individual, and guarantors are not able to make a reliable estimate of the risk of calls." 
- individual guarantees issued for public institutions like public corporations or local governments, public or private development banks; mostly for their investment financing operations

- programme guarantees provided for large groups of beneficiaries, as in guarantees on housing loans, student loans, export and SME credits

- guarantees extended to bonds issued by commercial banks

- individual bond guarantees in countries where public institutions borrow from capital markets.

The second group consists of contingent liabilities arising from projects realised under PPP models. PPPs are long term contractual arrangements between the government and a private partner whereby the latter delivers and funds public services using a capital asset, sharing the associated risks (OECD, 2012). Here the coverage is the government liabilities in the PPPs, which are explicit and contingent. In this context, PPP contingent liabilities include:

- financial guarantees in the form of credit and refinancing guarantees

- revenue guarantees

- exchange rate guarantees

- termination payment commitments

- debt assumption commitments

- $\quad$ sub-sovereign creditworthiness guarantees.

The third sub-group consists of government sponsored insurance programmes. Here, the scope again is explicit commitments by central government, which are also contingent upon some future events. Therefore, fully private insurance programmes are outside the scope of this study. Government sponsored insurance programmes are:

- deposit insurance programmes funded or explicitly supported by the government

- other government insurance programmes such as disaster risk insurance and terrorism insurance.

There are other sources of explicit contingent liabilities not covered by this study, such as legal claims against government, uncalled capital commitments to international organisations or country specific forms of government contractual liabilities carrying uncertainties.

Implicit contingent liabilities, on the other hand, are much wider in scope. As such, their management requires an orchestrated effort among various institutions and players in the economy. When realised however, their negative effects on the governments' fiscal positions are more significant than explicit contingent liabilities, as the recent global financial crisis has shown. Thus, it is important for debt managers to have the necessary risk awareness about implicit contingent liabilities, as well as other sources of fiscal risks. 
The present report is informed by results from the OECD Committee on Financial Markets (CMF) workstream covering both explicit and implicit financial sector guarantees, although it takes the specific and somewhat narrower perspective of a public debt and risk manager and focuses on explicit contingent liabilities only. As part of this workstream, the CMF has numerous studies on the benefits and costs of the extension of various financial safety net aspects, including on competition, incentives and risk-taking and taxpayer liabilities (see e.g. OECD, 2011 and Schich and Kim, 2011).

\subsection{Global crisis and contingent liabilities}

It has been more than eight years since the onset of the global financial crisis. Policy responses of governments aimed at mitigating the negative effects of the crisis especially over financial markets have resulted in sizable increases in government debt and further deteriorations in fiscal balances, ${ }^{9}$ Concern continues over the possibility of a sovereign debt crisis, impairing efforts to restore confidence among investors, financial intermediaries and households; and putting downward pressure on global economic growth.

Progress achieved in reducing fiscal imbalances in OECD countries has not been at sufficient levels to contain the public debt burden. Figure 1 shows central government marketable gross debt for different country groupings. Debt accumulation is higher in G7 countries affected most seriously by the crisis, while there is also an important increase in the OECD area of approximately $30 \%$ during the period 2007-2014. ${ }^{10}$

\section{Figure 1. Central government marketable gross debt in OECD countries}

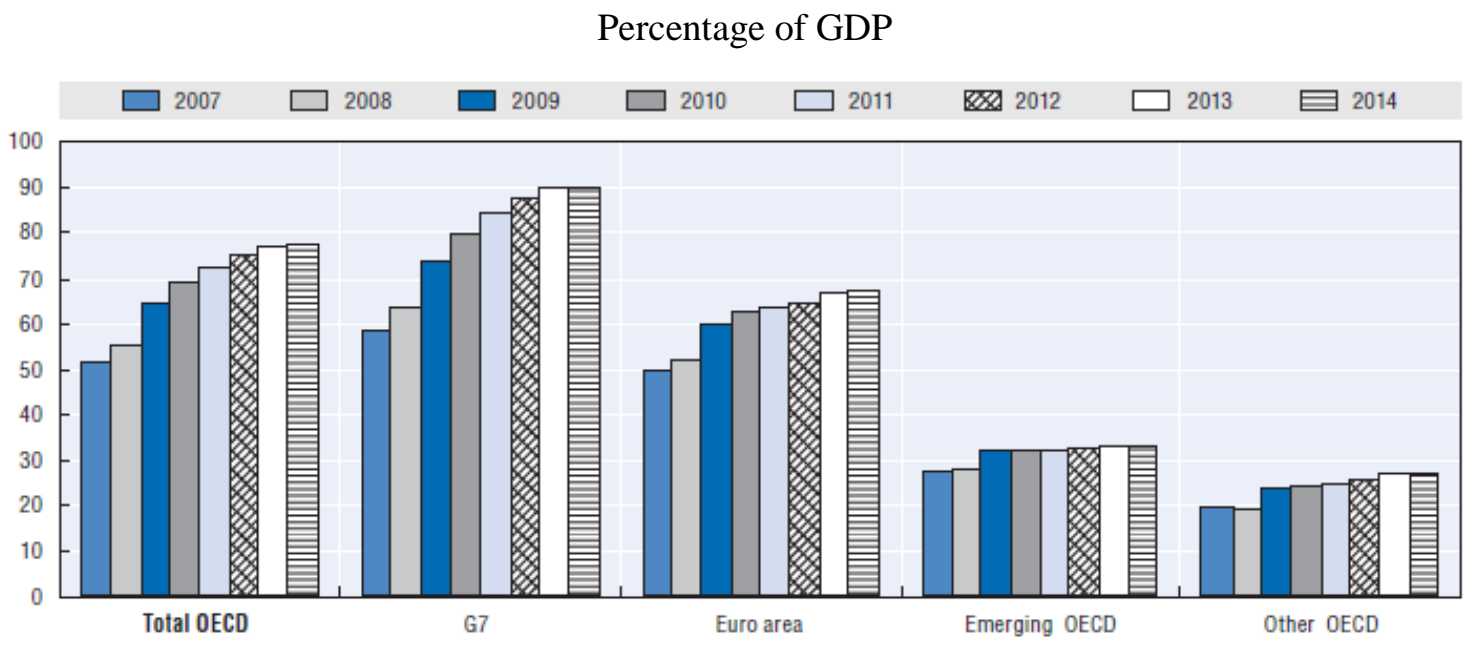

Source: OECD (2014), OECD Sovereign Borrowing Outlook 2014, http://dx.doi.org/10.1787/sov_b_outlk-2014-en

Large-scale support of governments to the financial sector was a characteristic of the post crisis environment, taking various forms including unlimited coverages for deposits, capital injections, asset purchases and finally yet importantly, guarantees on bank bonds. The policy responses have been

\footnotetext{
${ }^{9}$ For an analysis of post-crisis challenges for public debt management, see Blommestein, H. et al. (2010).

${ }^{10}$ For recent developments in sovereign borrowing based on different public debt indicators, see OECD Sovereign Borrowing Outlook 2014.
} 
effective in restoring financial stability and preventing bank runs, while the interventions with public funds have had significant repercussions for both markets and the government balance sheets.

Sovereign guarantees issued for banks' funding have been initially considered as a reflection of the implicit contingent liabilities of governments towards the financial sector. However, the prolongation of these explicit guarantee programmes in Europe and the US has raised discussions over their possible negative impacts on the risk and pricing mechanisms in financial markets ${ }^{11}$. The issuances of these government-backed bonds reached very high levels during 2009-2010 (Figure 2).

Figure 2. Gross issuance of bank bonds in the euro area, the UK and the US

Billions of Euro equivalents



Source: Grande G, et al. (2011), "Public Guarantees on Bank Bonds: Effectiveness and Distortions", www.oecd.org/finance/financial-markets/49200208.pdf

On the other hand, financial sector distress has created important effects on global capital movements and investment channels. Regulatory and restrictive measures taken to protect the financial system have led to a decrease in the risk appetite and willingness of banks to provide financing for infrastructure. The resulting financing gap has become an important issue for both developed and developing countries. In this environment, government guarantees, mostly taking the form of credit guarantees, have continued to be important tools of credit enhancement in infrastructure finance. On the other hand, in the framework of the PPP model of procurement, governments have increasingly resorted to the financial and other guarantees in order to increase the governments' share in project risks and thereby ensuring the projects' "bankability ${ }^{12 "}$.

The global crisis has posed significant troubles for the small and medium-sized enterprises (SMEs) as well. Work by the $\mathrm{OECD}^{13}$ reveals that access to finance and lending conditions deteriorated for the SMEs after the crisis, especially during the period 2007-2010, generally accompanied by modest or no growth in credit volumes. Responding to these developments,

\footnotetext{
${ }^{11}$ OECD has intensive work on financial sector guarantees since the 2008 global financial crisis available at www.oecd.org/finance/financialsectorguarantees.htm

${ }^{12}$ A PPP project is bankable if lenders are willing to finance it (The EPEC PPP Guide). www.eib.org/epec/g2g/iproject-identification/12/123/index.htm

${ }^{13}$ See "Financing SMEs and Entrepreneurs: An OECD Scoreboard" 2013.
} 
governments designed new SME guarantee programmes generally in the form of credit guarantees provided under special programmes or expanded the existing ones in order to boost SME financing in the post-crisis environment ${ }^{14}$. There have been changes in the total amount of guarantee funds, the share of the loans guaranteed or the number and types of eligible firms aimed at increasing the government support. In addition, these programmes included some new elements or new instruments over the traditional guarantee programmes (OECD, 2013). In general, the main objective of these programmes has been to enhance the SMEs' access to credit, especially to bank lending.

Figure 3 presents the increase in the level of contingent liabilities in the European context for the period 2007-2014. The data illustrate that in both the Euro Area (EA19) and the EU as a whole (EU28), there was significant increase in the stock of contingent liabilities in 2008 and 2009, before the gradual decrease in 2010 and 2011. The peak in 2009 reflects the large exposures of the European governments under the financial sector support programmes (in the form of guarantee schemes), and the subsequent decrease is largely the result of decreased exposures in Germany, Ireland, the Netherlands and the United Kingdom (Eurostat, 2015).

Figure 3. Level of contingent liabilities in the euro area and the EU 28 (2007-2014)

\section{Percentage of GDP}

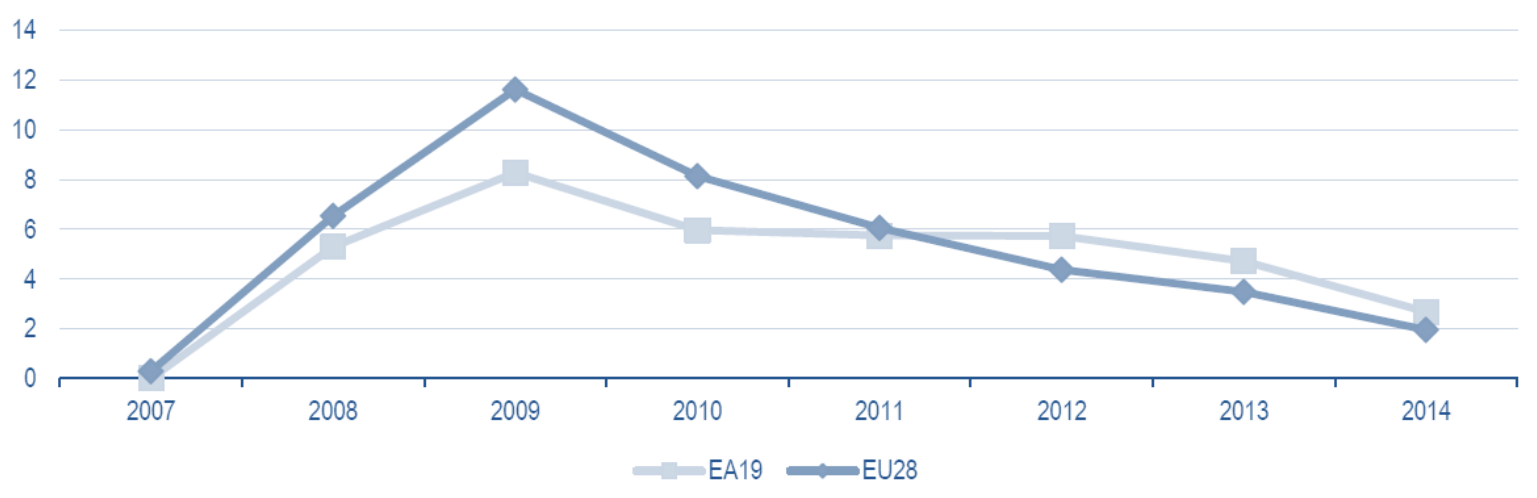

Source: Eurostat Supplementary Table for the Financial Crisis - Background note (April 2015) http://ec.europa.eu/eurostat/documents/1015035/2022710/Background-note-fin-crisis-OCT-2015-final.pdf

To summarise, the use of guarantees and other type of contingent liabilities by the governments have increased due to the global crisis. The areas where this increase was the most evident were; financial sector support, credit enhancement for infrastructure financing in traditional and PPP procurement models and the SME finance. Thus, the effective management and monitoring of contingent liabilities have become more important for governments.

Against this backdrop, the following parts of this paper focus on main components of contingent liability management and the role of public debt managers. Part II includes the summary results of the OECD survey and analyses the role of public debt managers in three sub-categories of contingent liabilities. Part III is a summary of conclusions and recommendations. Annex A presents the case studies of seven task force members drafted by the DMOs of the member countries themselves.

\footnotetext{
14 According to a survey conducted by OECD Working Party on Small and Medium Sized Enterprises \& Entrepreneurship (WPSMEE) on the Impact of the Global Crisis on SMEs and Entrepreneurship, "creation and extension of loan guarantee schemes" was a common policy response for all countries with only several exceptions. See OECD (2009).
} 


\title{
PART 2. THE ROLE OF PUBLIC DEBT MANAGERS IN CONTINGENT LIABILITY MANAGEMENT
}

The first section of this part presents the summary results of the OECD survey to provide readers with an overview of public debt managers' involvement in contingent liability management across countries. This part then analyses three categories of contingent liabilities; government credit guarantees, contingent liabilities arising from PPPs and government sponsored insurance programmes, and includes discussions on these policy areas from a PDM perspective.

\subsection{Summary of the OECD survey results}

The OECD Bond Market and Public Debt Management Unit conducted a survey on the role of public debt managers in contingent liability management in late 2013 among 34 OECD Countries and 2 non-OECD Countries (Brazil and South Africa). The survey questions were sent through e-mails to the authorities of DMOs and 31 OECD and 2 non-OECD countries responded to the survey.

According to the survey results, out of the 33 DMOs, 22 indicated that they have some role in the management of contingent liabilities. Figure 4 illustrates this result as a percentage.

\section{Figure 4. The role of DMOs in contingent liability management}

\author{
Responses to the question: Do you have any role in the \\ management of contingent liabilities?
}

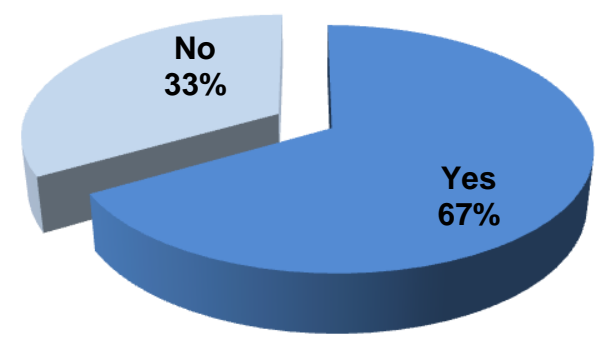

The survey also provided information on the involvement of DMOs in contingent liabilities by the type of liabilities (Table 2). The results indicate that the government credit guarantees is the category of contingent liabilities with which DMOs mostly engage. Programme guarantees - also included within the category of credit guarantees in this paper - government sponsored insurance programmes and the PPP guarantees are areas that a majority of DMOs participated in the survey do not assume responsibilities at the management level. 
Table 2. DMOs' involvement in the management of different types of contingent liabilities

Responses to the question: Is DMO responsible for the management of the following contingent liabilities at any level?

\begin{tabular}{lccc}
\hline & Yes & No & Total \\
\hline Government credit guarantees & 12 & 10 & $\mathbf{2 2}$ \\
\hline Programme loan guarantees & 3 & 16 & $\mathbf{1 9}$ \\
\hline Government insurance schemes & 2 & 17 & $\mathbf{1 9}$ \\
\hline PPP guarantees & 2 & 17 & $\mathbf{1 9}$ \\
\hline Other & 2 & 13 & $\mathbf{1 5}$ \\
\hline
\end{tabular}

The results also provided insights into the types of roles DMOs play in different areas of contingent liability management - measurement, monitoring and reporting. Monitoring and reporting roles of DMOs are more prominent when compared to the measurement in case of the credit guarantees. For the other types of contingent liabilities, the number of DMOs carrying these three functions is much less. The involvement of DMOs in the measurement, monitoring and reporting of contingent liabilities is slightly higher in every category when compared with their "responsibility in management".

Table 3. Types of roles DMOs play in different areas of contingent liability management ${ }^{(*)}$

\begin{tabular}{lccccccccccc}
\hline & $\begin{array}{c}\text { Do you calculate } \\
\text { the expected cost? }\end{array}$ & \multicolumn{2}{c}{$\begin{array}{c}\text { Monitored } \\
\text { regularly? }\end{array}$} & \multicolumn{2}{c}{$\begin{array}{c}\text { Reported regularly } \\
\text { and publicly? }\end{array}$} \\
& Yes & No & Total & Yes & No & Total & Yes & No & Total \\
\hline Credit guarantees & 11 & 8 & $\mathbf{1 9}$ & 17 & 1 & $\mathbf{1 8}$ & 17 & 1 & $\mathbf{1 8}$ \\
\hline Programme loan guarantees & 6 & 3 & $\mathbf{9}$ & 6 & 3 & $\mathbf{9}$ & 7 & 2 & $\mathbf{9}$ \\
\hline Government insurance schemes & 3 & 5 & $\mathbf{8}$ & 5 & 3 & $\mathbf{8}$ & 4 & 4 & $\mathbf{8}$ \\
\hline PPP guarantees & 5 & 2 & $\mathbf{7}$ & 5 & 2 & $\mathbf{7}$ & 4 & 3 & $\mathbf{7}$ \\
\hline Other (s) & 3 & 3 & $\mathbf{6}$ & 4 & 2 & $\mathbf{6}$ & 4 & 2 & $\mathbf{6}$ \\
\hline
\end{tabular}

${ }^{(*)}$ The fields left blank by the countries were not counted as "no" in the table.

As regards to the question about the possible effect of the global financial crisis on the role of the DMOs in contingent liability management; 13 countries mentioned some change in their role following the global crisis, and 9 of these countries linked this change to the support provided to the financial sector after the crisis (Figure 5). 
Figure 5. The effect of the global financial crisis on the role of DMOs

Responses to the question: Has there been any change in your role after the global financial crisis?

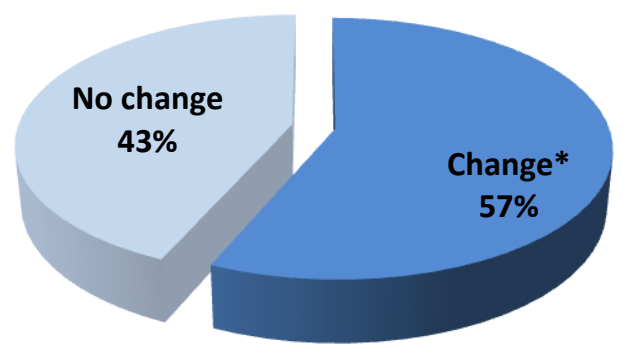

* In 13 DMOs where these has been a role change, in 9 (approximately $70 \%$ ) the change is related to the guarantees provided to financial sector institutions .

To summarise, the main findings of the OECD survey on the role of public debt managers in contingent liability management are:

- Around two-thirds of the DMOs responding to the survey have some role in contingent liability management.

- Government credit guarantees is the sub-category of contingent liabilities that the DMOs most actively engage.

- Contingent liabilities arising from PPPs and the government sponsored insurance programmes are the areas the public debt managers are not involved in management while a relatively small number of DMOs perform functions of measurement, monitoring and reporting in these areas as well.

- From the perspective of public debt managers, the effect of the global financial crisis on their contingent liability management practices was largely through their increasing role in the financial sector support programmes initiated within the crisis environment.

In the following sections, policy frameworks of government credit guarantees, contingent liabilities arising from PPPs and government insurance programmes will be discussed with their implications for public debt managers.

\subsection{Government credit guarantees}

Government credit guarantees are the liabilities based on contracts through which the government assumes the whole or part of the credit risk of a loan extended to or a bond issued by another party. In this study, the term refers to the guarantees covering debt service obligations of the beneficiaries.

Government credit guarantees are the most widely used explicit contingent liabilities in many countries and the results of the survey strongly supports this finding. Traditionally, this group consisted mainly of the individual guarantees provided for public institutions like public corporations or local governments, and for public or private development banks, mostly in the framework of their investment financing operations. In many developing countries, access to foreign financing sources by public institutions has been possible through the government guarantees provided on their foreign 
loans. The alternative to these government guarantees is the on-lending, in which case, the government borrows directly from the lenders and on-lends the funds under the same or different terms to the beneficiary institutions by means of a separate agreement ${ }^{15}$.

Programme or umbrella guarantees - labelled as programme loan guarantees in the survey- are usually provided for large groups of beneficiaries, as in guarantees on housing loans, student loans, export credits and the credits for SMEs. These guarantees are also debt service guarantees issued by the central governments. In most cases, programme guarantees are run by specialised agencies or institutions, as in the case of credit guarantee funds for SMEs or export credit agencies (ECAs) for the export credits. Considering the large number of beneficiaries involved, individual guarantee applications are dealt with within the programme parameters at the agency level, rather than at the central government level (such as the ministry of finance or treasury).

Guarantees issued by the governments for the bonds of the commercial banks in response to the financial crisis can also be evaluated as some form of government credit guarantees. As these guarantees were in the form of contractual guarantees, they are by definition explicit, irrespective of whether they were issued on some (until then) implicit commitments. ${ }^{16}$.

From the government's perspective, motivation for credit guarantee issuance is a function of its political and economic priorities and might change over time, depending on the developments in the domestic market and at the global level. For example, when boosting real sector development becomes a priority, guaranteed SME credits might be formulated, or in a financial crisis environment, bond guarantees are brought to the table to ease the banking sector distress. The main objective of the government in using credit guarantees as a financial instrument is, in general terms, to provide incentives for the market to finance certain institutions, activities or projects. By taking over the credit risk of the borrower, access to more funding from the lenders or investors is assured or the terms of the financing is ameliorated. Thus, the principal rationale is the same in different sub-categories of credit guarantees. For credit guarantees to be economically justified, however, they must bring advantages that outweigh these drawbacks. Each proposed guarantee (or programme) has to be evaluated on its own merits, including a careful evaluation of alternative solutions.

\section{Role of public debt managers}

The results of the survey show that compared to other forms of contingent liabilities, the area of government credit guarantees is the one with which debt managers are the most actively engaged. Public debt managers are involved in different phases of guarantee issuance; from assessing the credit guarantee proposals, to monitoring and managing the credit guarantee portfolios and programmes. The survey responses also indicate that DMOs were responsible for the management of the financial sector guarantee programmes, initiated in the European countries during the global financial crisis.

\footnotetext{
${ }^{15}$ The OECD (2005) provides a comparative analysis of credit guarantees and on-lending and concludes that credit guarantees have two drawbacks relative to direct lending. First and foremost, guaranteed debt has higher funding costs. For a guarantee to a government-owned entity or for a subsidised guarantee, this additional cost is borne by the government. Second, guarantees may entail higher financial risks, in particular if the borrower is able to set and implement its own financing policy. Such risks are transferred to the government as guarantor. To counteract such behaviour, the guaranteed borrowers must be subjected to monitoring, an activity which in itself is costly. The Annex A.2 on Denmark also includes an analysis of credit guarantees versus on-lending.

${ }^{16}$ Levy, A. and Schich, S (2010) and Grande G, et al. (2011) provide detailed analysis on the financial sector support programs involving government guarantees to bank bonds.
} 


\section{Assessment of credit guarantee proposals}

In case of individual (non-programme) credit guarantees, the criteria to be met by the applying institutions should be set clearly thereby the initial assessment for the guarantee eligibility becomes an easy task. This can be done by the front or mid office of DMO, or the related department of Treasury/Ministry of Finance, where the application is submitted, or the sponsoring ministry in more decentralised jurisdictions.

More importantly, assessment of a credit guarantee at the application stage requires a further quantitative analysis of the proposed guarantee at hand, revealing its potential costs and risks to the government. Ideally, the net cost/net benefit should be quantified through a cost-benefit analysis of the guarantee proposal though it is often difficult to quantify the benefits of a guarantee. In this regard, the guarantee should be valued and priced ex ante based on its expected and actual (mostly administrative) costs and risks, based on different contingent liability measures, with two initial purposes:

- inform the political decision-making body about the costs and risks of the guarantee before a decision is made for its issuance

- determine the level of fee to be charged from the beneficiary.

Operationally, these two analyses can be done in one stage or in two separate stages. The quantitative analysis should inform and supplement the eventually political decision to be taken by the legislature, cabinet or the minister, depending on the legal framework in place in a country. This information should also be provided in a way to enable the decision-maker to compare between the credit guarantee with other instruments like direct lending or subsidies in terms of its costs. For example, the risk assessment conducted by the State Guarantee Fund (SGF) of Iceland, which is the body within the Government Debt Management division of Central Bank, is submitted to the Parliament for the latter to decide if a financial subsidy should be provided instead of a guarantee. Ultimately, the policymaking body decides whether to issue the guarantee or not. A guarantee can be issued for political reasons or certain policy purposes even when the cost of a guarantee is relatively high.

According to the results of the OECD Survey, there are differences among countries in decisionmaking frameworks for issuing credit guarantees, but political decision-making supported by a quantitative assessment/evaluation of guarantee terms exists in many countries (Table 4). 
Table 4. Examples of credit guarantee issuance frameworks

\begin{tabular}{|c|c|c|}
\hline Country & Political decision-making & Quantitative analysis \\
\hline Austria & $\begin{array}{l}\text { Ministry of Finance receives and } \\
\text { evaluates applications for, and } \\
\text { decides on credit guarantees } \\
\text { according to the specifications within } \\
\text { the legal framework. }\end{array}$ & $\begin{array}{l}\text { The DMO (Austrian Federal Financing } \\
\text { Agency) evaluates whether the terms and } \\
\text { conditions of sovereign guarantee transactions } \\
\text { are in line with the market and in line with } \\
\text { legal limits regarding the maximum interest } \\
\text { cost (No calculation of expected cost though) }\end{array}$ \\
\hline Canada & $\begin{array}{l}\text { Legislation is required for credit } \\
\text { guarantees, thus the Parliament is the } \\
\text { decision-making body. }\end{array}$ & $\begin{array}{l}\text { Ministry of Finance maintains guidelines, } \\
\text { evaluates and provides policy advice on the } \\
\text { need and justification for providing credit } \\
\text { guarantees based on guidelines that address } \\
\text { risks and potential costs. }\end{array}$ \\
\hline Iceland & $\begin{array}{l}\text { Parliament issues a separate } \\
\text { legislation for each guarantee it } \\
\text { approves. The Ministry of Finance } \\
\text { presents the bill to the Parliament. }\end{array}$ & $\begin{array}{l}\text { The SGF, a separate body within the Central } \\
\text { Bank Government Debt Management } \\
\text { Subdivision, conducts the necessary risk } \\
\text { assessment exercise. The opinion of the SGF is } \\
\text { a condition for sending the bill to the } \\
\text { Parliament. }\end{array}$ \\
\hline Mexico & $\begin{array}{l}\text { Minister of Finance decides whether } \\
\text { to authorise guarantees or not. }\end{array}$ & $\begin{array}{l}\text { The DMO or the Ministry of Finance conducts } \\
\text { no quantitative analysis during the decision- } \\
\text { making. }\end{array}$ \\
\hline Netherlands & $\begin{array}{l}\text { Ministry of Finance must approve all } \\
\text { guarantee proposals. }\end{array}$ & $\begin{array}{l}\text { DSTA in consultation with the Central Bank is } \\
\text { the agency evaluating the guarantee } \\
\text { applications of banks, also calculating the fee } \\
\text { to be charged from these banks. }\end{array}$ \\
\hline South Africa & $\begin{array}{l}\text { Minister of Finance, or another } \\
\text { cabinet member with the concurrence } \\
\text { of the Minister of Finance, decides on } \\
\text { the issuance of guarantees. }\end{array}$ & $\begin{array}{l}\text { Fiscal Liabilities Committee (FLC) chaired by } \\
\text { the Asset and Liability Management (ALM) } \\
\text { Division of Treasury evaluates the quantitative } \\
\text { analysis including the risk assessment } \\
\text { conducted by the ALM Division at each } \\
\text { application. }\end{array}$ \\
\hline Sweden & $\begin{array}{l}\text { The Parliament decides on the } \\
\text { purpose and the amount of the credit } \\
\text { guarantee. In case of the guarantee } \\
\text { programmes, single authorizations are } \\
\text { issued by the Parliament. }\end{array}$ & $\begin{array}{l}\text { The responsible authority analyses the credit } \\
\text { risk of the undertaking, decide upon the terms } \\
\text { of the guarantee, and calculate a fee that will } \\
\text { cover the expected cost (or a higher fee to } \\
\text { comply with international agreements). }\end{array}$ \\
\hline Turkey & $\begin{array}{l}\text { Minister responsible from the } \\
\text { Treasury has the authority to issue } \\
\text { government credit guarantees, within } \\
\text { the nominal limits set by the } \\
\text { Parliament through the annual budget } \\
\text { law. }\end{array}$ & $\begin{array}{l}\text { Credit Risk Management Department within } \\
\text { the Treasury informs the front office about the } \\
\text { credit rating category of the applicant based on } \\
\text { an internal model at each credit guarantee } \\
\text { application. After the decision is made, the fee } \\
\text { is calculated by using the same model. }\end{array}$ \\
\hline
\end{tabular}

Source: OECD 2013 Survey on the Role of Debt Managers in Contingent Liability Management 
In some cases, debt managers are given the mandate to perform the quantitative analysis both at the proposal assessment stage of the credit guarantees and for managing the portfolio (which will be discussed later). Public debt managers tend to have a broad perspective on government finances, thus they may be expected to make unbiased assessments of the costs and risks. Their general financial and economic expertise may also be helpful in making the analyses necessary to determine an appropriate fee. On the other hand, guarantee pricing requires capacity development in credit and project evaluation, and financial statement analysis to calculate default probabilities of institutions. These areas of expertise are not searched for in conventional debt management. Conducting default analysis of different types of institutions; SOEs, local administrations, public banks, and private investment banks, etc. might be challenging and requires a credit risk management function to be established within the debt management offices. Hiring credit risk specialists (the SNDO in Sweden and SGF in Iceland) or using a tailor-made credit rating model designed by credit risk management specialists hired for this purpose (Turkish Treasury) might be considered as other solutions, which enable tackling with these challenges.

In case of programme guarantees, which are usually authorised by the parliaments and involve many borrowers, additional aspects should be considered. Common practice is that the governments administer these guarantee programmes through specialised agencies and institutions - such as ECAs, credit guarantee funds/corporations specialized in SME guarantees, housing funds or agencies providing student loan guarantees - rather than assigning their management to DMOs. For efficient public financial management, these programmes should have clearly stated objectives and a set of rules for granting specific types of guarantees in order to provide the framework in which the unit responsible for issuance of these guarantees operates. In countries where centralised risk management function is performed by DMOs, the expected costs and risks of these guarantees should be taken into account in their overall risk assessment.

\section{Contract Design}

Credit guarantee contracts should be formulated in such a way as to clearly identify the scope and the terms of the guarantee. Governments limit the guarantees they issue, in time and amount for fiscal risk management purposes. For example, "The Guidelines of Borrowing and Risk Management" of Denmark stipulates that loan types must be customary, i.e. known and used in the market by reputed borrowers and loans must be built up from simple elements that make them transparent (plain vanilla products), to be eligible for guarantees". To give another example, in Swedish legal framework, it is envisaged that any guarantee undertaking must include contractual terms that limit the state's risk and ensures that the state has appropriate rights to monitor and control the risk.

Guarantee agreement between the lender and the government and the loan agreement between the lender and the borrower institution are parts of the same financial package. There is usually a third agreement (or protocol) between the government and the borrower regulating mostly the fee charging and recovery issues. Being as such, the terms of these agreements are highly correlated including cross-references to each other. The governments should play an active role in drafting the whole package of agreements to ensure proper clauses are in place regarding issues such as:

- collateral and counter-guarantee (if there are any)

- guarantee fee and administrative costs to be charged from the borrower

- rules and procedures to be followed when the guarantee is called

- financial and information sharing obligations of the lender and the borrower towards the government as the guarantor 
- sanctions for noncompliance

- case of default and the step-in conditions of the government as the guarantor

- recovery (collection procedures of the government pay-outs), etc.

The level of involvement of debt managers in the contract design and negotiations depends on the institutional framework for the issuance of credit guarantees. In countries where DMO has the authority to issue the guarantees, it is naturally involved with the contract drafting, negotiation and execution processes as the contracting party. However, in decentralized structures where the institutions other than the debt management office/Treasury/Ministry of Finance have the authority to issue guarantees such a direct involvement might not be the case.

\section{Risk management of the credit guarantee portfolio}

Risk management of the credit guarantee portfolio is a crucial function of governments meaning in simple terms, taking necessary measures to monitor and mitigate the fiscal risks posed by the already issued guarantees. The most common risk management tools employed by countries are: i) a limit or ceiling over the guarantee issuance or stock ii) a contingency reserve fund iii) partial guarantee issuance, iv) portfolio monitoring and v) disclosure and reporting.

Countries with strong capacity in managing risks of their direct debt portfolio are in a better position to perform this function over their guaranteed debt portfolio. Well-structured DMOs may expand their areas of responsibility to cover the risk management of contingent debt alongside the direct debt, enabling an integrated portfolio approach to risk management. For example, the Irish Debt Management Agency (NTMA) has evolved from a single function agency to the manager of a complex portfolio of public assets and liabilities. Likewise, the New Zealand DMO has recently assumed the role to monitor contingent liabilities as part of the responsibility of managing the Crown Balance Sheet. In April 2013, the DMO acquired the Balance Sheet Monitoring unit within the New Zealand Treasury, playing a more influential role in the management of contingent liabilities.

Across the countries applying limits, the types and scope change. Some countries apply an overall limit for all the contingent liabilities or even direct debt and contingent debt together, while in some others credit guarantees, guarantees issued under certain programmes (like bond guarantees for the banks), under the PPP frameworks, etc. are subject to separate ceilings. The scope of the limit might apply to the central government issuances or be extended to cover the general government. Some examples of guarantee limits are given in Table 5.

Another issue is whether to limit the government's exposure to the credit risk of a single institution, in order to confine the concentration risk of the portfolio. Within well-established frameworks where the applications are filtered through a process in which the creditworthiness of the applicant is measured and reflected on the guarantee fee, concentration risk might not be regarded as a major concern. However, where the incentivising motives of the government is high, issuing large amounts of guarantees to certain institutions continuously, even when there is an overall limit might increase the risk on the government's side.

In jurisdictions where parliamentary approval is a rule for each guarantee issuance, limiting the exposure might be less of a concern than in those where guarantee decisions are taken at the ministerial, cabinet or separate authority level.

Limiting the credit risk exposure by limiting the duration of certain guarantee programmes designed for exceptional circumstances is also recommended in order to avoid moral hazard and prevent the government support through guarantees to be regarded as a normal way of business. For 
example, our survey results indicate that the government guaranteed bank bonds issued after the global crisis were designed to be limited in time and amount.

When the guarantee limit is set and revised annually, the calculation of the limit to be applied for the subsequent year should be based on the valuation of the existing guarantee portfolio and the pipeline of new projects and activities together. Thus, limit-setting exercise could also be an area of involvement for the debt managers, which might be regarded as a side work of guarantee valuation.

\section{Table 5. Examples of guarantee limits applied in countries}

\begin{tabular}{ll}
\hline Country & Limit applied \\
\hline Brazil & $\begin{array}{l}\text { The amount of guarantee provided by the federal government must not exceed } 60 \% \text { of its } \\
\text { current net revenues on an annual basis. }\end{array}$ \\
Finland & Annual budgetary limit \\
Iceland & Annual budgetary ceiling for each SOE \\
Mexico & $\begin{array}{l}\text { The federal government guarantees the liabilities of national development banks (NDBs); } \\
\text { the limit is provided through the annual authorization given for their domestic market } \\
\text { operations. There are also congressional ceilings for the borrowings of the NDBs from } \\
\text { foreign markets. }\end{array}$
\end{tabular}

South Africa

There is no limit specific to guarantees in terms of total guarantees that can be issued, however a prudential sustainable debt level benchmark of net debt, provision plus contingent liabilities is used. The current limit for this benchmark is $60 \%$ of GDP.

Spain

Total amount of credit guarantees to be granted during concerned fiscal year have to be included in annual budget law, which is approved by the parliament. The budget law specifies potential beneficiaries, maximum amount and deadline for the granting of the guarantees.

The government delegates the parliament's approvals to issue guarantees to the related
authorities annually under separate ceilings.

Turkey

Total amount of new issuances of credit guarantees and on-lending is subject to limits set by the budget law of the fiscal year. The limit for the year 2015 is USD 3 Billion.

Source: OECD 2013 Survey on the Role of Debt Managers in Contingent Liability Management

In countries where reserve fund application exists, its cost effective management can be regarded as an area linked with guarantee valuation and portfolio management. Fund management involves monitoring the revenues (fees and collections from past pay-outs) and expenses (pay-outs for guarantees called) of the fund (generally back offices in debt management offices are good candidates 
to perform this function), managing fund's assets and calculating the need for budgetary allocations when the fund resources fall short.

Table 6. Country examples of reserve funds

\begin{tabular}{ll}
\hline Country & Reserve fund \\
\hline South Africa & $\begin{array}{l}\text { South Africa does not currently have a reserve fund, but one of the mandates of the FLC is to } \\
\text { consider the introduction of a funded contingency reserve account. }\end{array}$
\end{tabular}

\section{Sweden}

Each responsible authority keeps a "notional reserve account" at the SNDO. There is an unlimited credit linked to each reserve. A call on state guarantee is booked against the applicable nominal reserve and the resulting payment is charged against the Treasury Single Account. In addition, the fees and recoveries are recorded in these nominal accounts and then transferred into the central government revenues to decrease the SNDO's borrowing requirement.

\section{Turkey}

Turkish contingency reserve account (called "risk account") was established in 2003 at the Central Bank with the purpose of funding needs arising from of the credit guarantees. It is an actual and off-budgetary fund. The revenues of the fund consist of the collections from past pay-outs, guarantee/on-lent fees and interest income. If these revenues do not meet the need for undertakings, budgetary allocation for the risk account is utilised.

\section{USA}

Loan guarantees fund in USA is an example of notional reserve funds. It is an off-budget fund where the beneficiaries or the sponsoring departments pay the fees for guarantees. The transactions of these accounts are presented in budget documents.

Source: OECD 2013 Survey on the Role of Debt Managers in Contingent Liability Management, Cebotari (2009)

Issuance of partial credit guarantees, i.e. providing guarantee coverage for a percentage of the debt service obligations of the beneficiary, is a useful tool to establish a risk sharing arrangement between the government and the lender. Through leaving a certain portion of the loan or bond uncovered, the government can ensure that lender or investor carry some credit risk as well. Another tool to provide partiality is obliging the guarantee beneficiary to provide some part of the total financing for the project/activity in question.

In Turkey, for example, Treasury repayment guarantees are provided for up to $95 \%$ of repayments of the agreed credit amount. Partial guarantee does not apply to the loans from international and regional organisations, foreign government funds, and export credits provided by the official export insurance agencies of foreign countries; because of their concessional terms compared with commercial loans. In Iceland, this ratio is limited to $75 \%$ of the credit amount. In addition, the guarantee recipient is required to provide at least $20 \%$ of the total financing for the project. In Canada, lender-risk sharing is ensured by leaving $15 \%$ of the default risk to the lenders. 
Centralisation of the risk management function requires close monitoring of the portfolio, which is possible only by having access to information on the existing guarantees. Portfolio monitoring has two legs in general:

- monitoring of the disbursements and payments under the instrument on which the credit guarantee is established, and

- monitoring the financials of the beneficiary to be informed about its financial health in order to assess its ability to service guaranteed debt

Regarding the first one, the survey results show that in many OECD countries DMO is the place where data on existing guarantees are gathered even if it is not the issuer of some of those guarantees. The debt manager might use the data collected for the following purposes:

- valuation of the existing portfolio to assess fiscal risks that the central government is exposed

- $\quad$ informing the related bodies or parties (the Parliament, Cabinet, Finance Minister etc. ) about such risks

- using the guarantee information as an input in debt sustainability analysis (see section below)

- publishing the information on the web-site

- publishing the information as part of debt management reporting.

Institutional arrangements should be made in such a way as to make the data collection easier. In South Africa, for example, the data on utilisation from the existing guarantees are collated by the ALM Division (Credit Risk Directorate) of Treasury to be able to make overall risk based assessments of the portfolio and to produce recommendations to the FLC on a quarterly basis. Establishing a special guarantee-monitoring unit within DMO might also be useful. In Turkey, there is a separate division within the Treasury back office to monitor the guarantee portfolio, while the credit risk department in the middle office conducts the portfolio risk assessments. The flow of information to this monitoring unit might be direct or indirect through the fiscal reporting, which must be provided by the individual agencies to the Ministry of Finance.

Portfolio monitoring at the central level should ideally cover the whole portfolio of explicit contingent liabilities in which the portfolio of credit guarantees constitutes the most prominent part in most of the countries.

As regards to the disclosure and reporting, both quantitative and qualitative information on credit guarantees should be disclosed based on their expected costs and in such a way as to give a complete picture of the government's total financial position, both as part of debt management reporting and budgetary documentation.

Countries have different practices in credit guarantee disclosure and reporting, both as regards to the content of the data they disclose and to the forms of disclosure (web reporting, budget document, separate periodical report, etc.) (Table 7). 
Table 7. Disclosure practices of selected countries

\begin{tabular}{|c|c|}
\hline Country & Disclosure practices \\
\hline Austria & $\begin{array}{l}\text { Ministry of Finance, Risk Management Department reports credit guarantees 2-3 times a year } \\
\text { to the heads of the General Directorate (Internal reporting). Parliament is informed regularly } \\
\text { about all credit guarantees. The information about guarantees is announced to public through } \\
\text { federal annual report, at least once a year. }\end{array}$ \\
\hline Belgium & $\begin{array}{l}\text { onthly, the Treasury does trimestral and annual reporting. Reports are sent to the National } \\
\text { ank of Belgium, European Commission and other related parties. }\end{array}$ \\
\hline Canada & $\begin{array}{l}\text { utstanding credit guarantees are published annually in the Public Accounts of Canada } \\
\text { epared by the Receiver General of Canada. This document is available to the public. }\end{array}$ \\
\hline Finland & $\begin{array}{l}\text { ata on guarantees are collected by the DMO and reports are prepared and submitted to } \\
\text { tatistics Finland (SF). SF publishes the data. }\end{array}$ \\
\hline Greece & $\begin{array}{l}\text { ata on guarantees are made publicly available in the annual budgetary documents and annual } \\
\text { lance sheet. }\end{array}$ \\
\hline Iceland & $\begin{array}{l}\text { Annually, the SGF sends to the Ministry of Finance and Economic Affairs (MoFEA) a } \\
\text { comprehensive report on government guarantees, where an overview is given of the prospects } \\
\text { of each beneficiary of government guarantee, A risk assessment is made and an estimate is } \\
\text { given on the potential loss to the Treasury of credit guarantees falling in arrears. The report also } \\
\text { enumerates various suggestions by the SGF regarding further development in managing, } \\
\text { monitoring and reporting on government guarantees. Market Information Bulletin contains } \\
\text { information on guarantees (stock, currency distribution and comparison with direct debt and } \\
\text { GDP). }\end{array}$ \\
\hline Japan & g amount of government guaranteed debt is released quarterly. \\
\hline Mexico & $\begin{array}{l}\text { The DMO has the mandate to issue a quarterly report for the congress where it describes the } \\
\text { general status of public debt. As part of such mandate, all explicit contingent liabilities backed } \\
\text { by the Federal Government have to be duly described in a specific section. All contingent } \\
\text { liabilities are reported at notional value rather than expected value. }\end{array}$ \\
\hline Netherlands & $\begin{array}{l}\text { A monthly update is given on outstanding guarantees under the credit guarantee scheme. (The } \\
\text { list of bonds issued with government guarantees are given including the amounts outstanding). }\end{array}$ \\
\hline South Africa & The information with regard to contingent liabilities is published annually in the budget review. \\
\hline Spain & $\begin{array}{l}\text { Credit guarantees are recorded in the central government accounting system in specific } \\
\text { accounts. All contingent liabilities linked to a specific guarantee are recorded. Bank of Spain } \\
\text { and Ministry of Finance are informed monthly of the amounts and status of each guarantee. } \\
\text { Parliament is informed on a quarterly basis. Public data on GGBs are available at the Treasury } \\
\text { web site (weekly updated). Besides, Bank of Spain publishes monthly State guarantees data at } \\
\text { aggregate level. }\end{array}$ \\
\hline Sweden & $\begin{array}{l}\text { Each agency is responsible for reporting outstanding guarantees in its annual and semi-annual } \\
\text { report to the government. Representative features are current exposures, expected losses, size } \\
\text { of nominal reserves and recorded cash flows (e.g. payments, collected fees and recoveries). } \\
\text { There is also a specific section regarding the accumulated guarantee and on-lending portfolio in } \\
\text { the government's annual statement to the Parliament. Closely tied to this statement is a separate } \\
\text { report with additional information about risk in the aggregated portfolio, i.e. a report that goes } \\
\text { beyond regular accounting with respect to in-depth information. This includes for example } \\
\text { prospective losses due to guarantees of non-performing loans, analysis of unexpected loss with } \\
\text { respect to any portfolio concentrations (e.g. industry concentrations, geographical } \\
\text { concentrations or single name concentrations) and systematic risk plus an evaluation of the risk }\end{array}$ \\
\hline
\end{tabular}




Country Disclosure practices
of marginally higher borrowing costs with respect to potentially large and quick payments due
to calls on outstanding guarantees. All reports are publically available.
The monthly "Public Debt Management Report" is prepared and published by the General
Directorate of Public Finance of Treasury. It contains data related to public debt management
including Treasury guarantees provided, Treasury guaranteed debt stock, undertaken amount
from these guarantees in addition to other statistical data on direct or contingent liabilities of
Treasury such as Risk Account transactions, grants, on-lending of external debts etc. The report
is updated monthly and is posted on the Treasury website (www.treasury.gov.tr). A descriptive
version of the report is published on annual basis.

Source: OECD 2013 Survey on the Role of Debt Managers in Contingent Liability Management

\subsection{Contingent liabilities arising from PPPs}

The use of the PPP model of procurement for realizing public investment projects has a long history as an alternative method to traditional public procurement. The PPP model is described by the OECD Principles (2012) as "...long term contractual arrangements between the government and a private partner whereby the latter delivers and funds public services using a capital asset, sharing the associated risks" $" 17$.

Despite significant benefits offered by PPPs, most important one being the employment of private sector's efficiency and resources for the purpose of delivering public services, there are yet many challenges posed by this model. Most importantly, the complexity of the model necessitates skilful management on the public side, which brings about certain capacity building issues.

The IMF warns that PPPs might entail significant fiscal risks, and draws attention to the actions to help mitigate these fiscal risks. Strengthening the legal provisions affecting PPPs, strengthening the management and oversight frameworks, achieving full and transparent disclosure of all fiscal risks and fully integrating the accounting for and reporting of PPPs in the medium-term budget process are the actions that the IMF recommends (IMF 2014).

Cash flows generated by PPPs are generally quite different from those under the traditional public procurement. It might require less public money during the initial years of the contracts, as the investment is usually financed by private equity and finance. This perception makes PPPs relatively more attractive to governments, especially to ones with fiscal constraints. However, when the fiscal costs of the public investment are analysed over the life of the project, the choice for a PPP might not be justified.

While the rise in the interest for PPPs in recent years is evident, the available data suggests that there have been considerable falls in the number of PPP deals in the aftermath of the crisis, especially in Europe, as the access to long term private financing sources has become more difficult (Figure 7) ${ }^{18}$.

\footnotetext{
17 As also noted in the OECD Principles, there is no commonly agreed definition of the PPPs, different definitions are used by different international institutions and countries. The fact that there are a variety of models under the "PPP" category with specific ownership structures makes agreement over a unified definition more difficult.

${ }^{18}$ January 2010 Survey by the OECD, presented in "How to Attain Value for Money"
} 
The collapse of the monoline ${ }^{19}$ industry due to the crisis, which was important in providing financial guarantees over bonds issued by project companies to finance PPPs, and the new and more restrictive Basel III capital requirements for banks; are some of the factors exacerbating the limitations of private investment finance.

In recent years, direct and contingent commitments provided by the governments under the PPP frameworks have been sought for more and more by the private sector companies and lenders. The European Public Private Partnership Expertise Centre (EPEC) confirms this trend by noting "Limited liquidity in the PPP financing markets, increased risk aversion of lenders and sponsors and a higher cost of capital have led governments to take a more active role in providing direct and indirect financial support to PPP programmes. So far, government support has often been provided through financing non-government partners' capital costs, granting extensive guarantees to creditors as well as agreeing to more generous PPP contract termination clauses" (EPEC, 2010). However, as data availability on the contingent commitments embedded in PPP contracts is very limited, it is not possible to show this rising trend across countries ${ }^{20,21}$. It should also be noted that the current low interest rate environment in the international financial markets is a factor boosting investors' willingness to finance PPPs, which might result in a reduced need for the government guarantees aiming at credit enhancement in the coming years.

\section{Figure 6. European PPP market by value and number of projects}

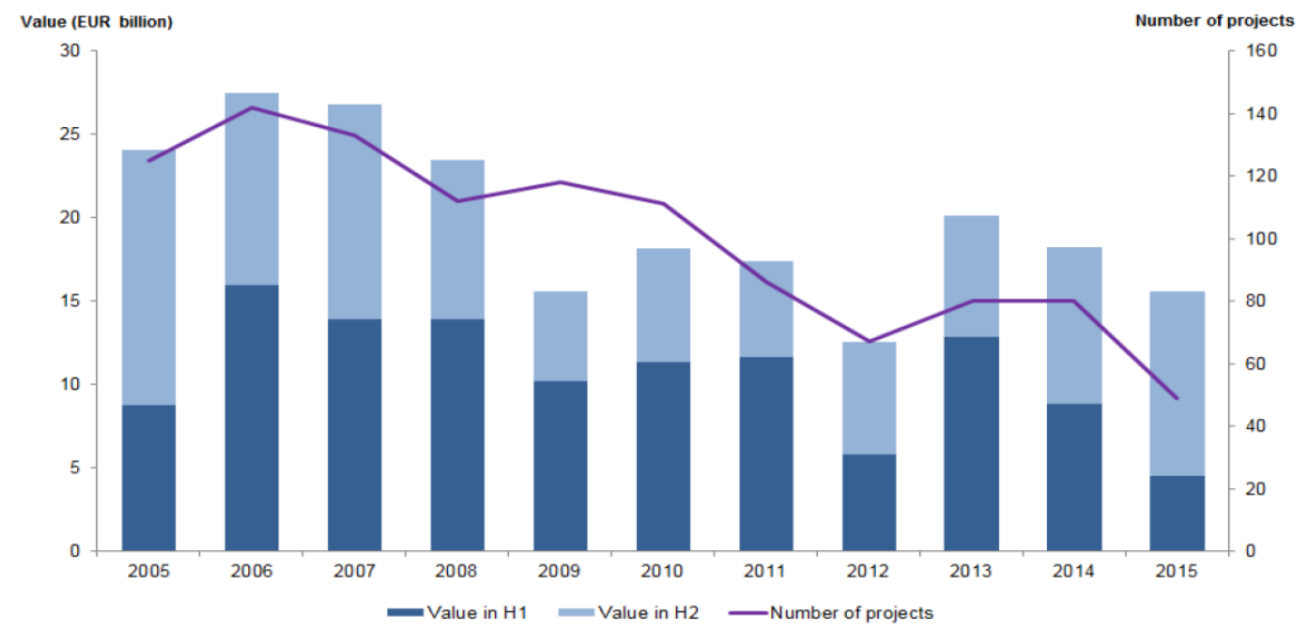

Source: EPEC (2016), Market Update, Review of the European PPP Market in 2015, www.eib.org/epec/library/epec_market_update_2015_en2

19 "Monoline industry" involved companies which are called "monolines" because, although they are legally licensed and organised as insurance companies, they are permitted by law to offer only one form of insurance - financial guarantees - as opposed to other insurance companies which may offer various insurance products and are called "multi-line" insurers (EPEC 2010).

${ }^{20}$ Eurostat data covers PPPs from 2010 onwards but the data is on "adjusted capital value of balance PPPs", not the specific contingent liabilities involved.

${ }^{21}$ According to a 2009 Survey conducted by Philippe Burger, Justin Tyson, Izabela Karpowicz, and Maria Delgado Coelho as discussed in "The Effects of the Financial Crisis on Public-Private Partnerships", half of the respondents saw the key VfM criteria for new projects changing-specifically, private partners in PPPs were less willing to retain certain risks, such as interest rate risk and financial closure risk and were seeking greater contributions or guarantees from the government. 


\section{Types of contingent liabilities in PPPs}

For the purposes of this report, PPP contingent liabilities cover those contingent commitments, which are based on contracts ${ }^{22}$ signed by the central government institutions for PPPs. The noncontractual or implicit PPP liabilities, which are materialized mostly when the politically important projects are bailed out by the governments, or when the governments have to renegotiate PPP contracts, are outside the scope of this report.

On the other hand, direct fiscal commitments of governments under the PPPs; like up-front capital contributions or availability payments of governments committed during the life of the project are not covered because these are not contingent but direct liabilities of the governments. However, it is important to acknowledge that these long-term direct fiscal commitments are also important sources of fiscal risk and should be monitored closely for ensuring fiscal sustainability.

Within this context, the main contingent liabilities under PPPs are:

- credit and refinancing guarantees extended to the project companies under which the government guarantees the lenders that it will service their debt if the PPP company fails to do so.

- revenue guarantees, where the government guarantees the project company a certain level of usage of the services to be provided by the latter.

- exchange rate guarantees, which means the government assumes the exchange risk of the project company, usually when the project's main cash flows are denominated in a foreign currency.

- termination payments, which are government commitments to pay the project company a certain amount in case the contract terminates prematurely, where the principle is that this amount corresponds to the value of the project assets, but in some cases the government commits to pay a certain portion of the debt outstanding to the lenders

- debt assumption commitments, where the government agrees to assume the debt obligations of the project company in case the PPP contract is terminated. Compared to the terminations payments, the debt assumption commitments are towards the lenders, not the project company.

- guarantees extended to the commitments provided by non-sovereigns (non-sovereign creditworthiness guarantees), which aim at increasing the creditworthiness of commitments provided by non-central government entities.

Table 8 provides examples of these various types of contingent liabilities by the countries that use them in their PPP contracts.

It is also useful to distinguish between different layers of direct fiscal commitments and guarantees provided under PPPs (Aslan and Duarte, 2014). Grantor or procuring public institutions

\footnotetext{
${ }^{22}$ The main contract signed under the PPP models is the implementation contract between the procuring institution and the project company, which is usually called "the PPP contract". There are other contracts and sub-contracts regulating mainly the credit, hedging, insurance, construction, operation and maintenance issues signed between the related PPP players.
} 
can themselves provide some forms of direct fiscal commitments or guarantees to the project companies or the creditors for various project risks, depending on the authority given to them by the domestic PPP legislations. The second layer of guarantees are provided by the central government authority/financial authority (ministries of finance or national treasuries in most cases) to support the first level of commitments or provide additional guarantee coverage for certain risks. Aslan and Duarte highlight the importance of ensuring coordination between these two levels of institutions considering that the implementing institutions would be more prone to take risks to accomplish their investment agenda than the finance ministry/treasury, which would be more cautious about the impact of these contingent liabilities on the central government budget and debt sustainability.

Table 8. Examples of state guarantees in PPPs

\begin{tabular}{|c|c|}
\hline Country & Type of guarantee/contingent liability \\
\hline Belgium & $\begin{array}{l}\text { Refinancing guarantees } \\
\text { Loan guarantees } \\
\text { Sub-sovereign creditworthiness guarantees }\end{array}$ \\
\hline France & $\begin{array}{l}\text { Loan guarantees } \\
\text { Refinancing guarantees } \\
\text { Guaranteed minimum service charges } \\
\text { Termination payments } \\
\text { Guaranteed debt instrument }\end{array}$ \\
\hline Germany & Guaranteed minimum service charges \\
\hline Greece & Sub-sovereign creditworthiness guarantees \\
\hline Italy & $\begin{array}{l}\text { Revenue guarantees } \\
\text { Sub-sovereign creditworthiness guarantees } \\
\text { Credit guarantees }\end{array}$ \\
\hline Portugal & Loan guarantees \\
\hline Spain & Termination payments \\
\hline Turkey & $\begin{array}{l}\text { Revenue guarantees } \\
\text { Debt assumption undertakings }\end{array}$ \\
\hline United Kingdom & $\begin{array}{l}\text { Termination payments } \\
\text { Bespoke guarantees on transaction basis }\end{array}$ \\
\hline
\end{tabular}

Source: EPEC (2011), State Guarantees in PPPs: A Guide to Better Evaluation, Design, Implementation and Management http://ec.europa.eu/eurostat/web/government-finance-statistics/data/database

It is important to note that some of the guarantees provided by the EPEC members in PPPs have been initiated in response to the global crisis, such as the debt instrument in France, refinancing guarantee in Belgium and loan guarantees in Portugal (EPEC 2011). 


\section{PPP Governance}

OECD Principles for Public Governance of Public Private Partnerships ${ }^{23}$ (2012) maps out the key players and their responsibilities in PPPs (Table 9). The OECD recommends that there should be a body at the central government level approving the PPPs, and this approval decision should be taken based on sufficient information on the costs and risks of the project. OECD also advises that in order to avoid conflict of interest, the unit promoting the PPP and the unit approving the investment decision should be separated. The approving agency should have an understanding of the government's fiscal situation and an interest in maintaining prudent fiscal policy.

Institutional set-ups for PPP governance differ widely across countries. In some countries there is no PPP unit performing the functions that are recommended by the OECD. ${ }^{24}$ PPPs are long-term contracts calling for strong project management and monitoring skills not only within the private parties but also on the side of governments. As part of this broader context, the monitoring and management of long term PPP contingent commitments should also be an area of concern for the governments and be dealt with at the central government level.

\section{Table 9. Key players and their roles in PPP Governance}

\begin{tabular}{ll}
\hline Procuring authority & $\begin{array}{l}\text { Responsible for the project, including the preparation, } \\
\text { negotiation and administration of the contract, monitoring and } \\
\text { evaluating the contract performance during the construction } \\
\text { and operation phases of the project }\end{array}$ \\
& $\begin{array}{l}\text { Equipped with specific skills to ensure value for money } \\
\text { help the authorities, especially the procuring authority to } \\
\text { design, manage and evaluate the project efficiently }\end{array}$ \\
PPP company & $\begin{array}{l}\text { Private sector company responsible for undertaking the PPP } \\
\text { project, which is assigned this duty by the procuring authority } \\
\text { the special purpose vehicle }- \text { SPV) }\end{array}$ \\
Audit institution & $\begin{array}{l}\text { Conducts the ex-post auditing and assessment of the PPP and } \\
\text { reports to the Parliament }\end{array}$ \\
Central budget institution to monitor and check the project \\
throughout its key phases; planning, feasibility, design, \\
bidding, contract execution, construction and operation (In \\
order to avoid conflict of interest, it should be the central \\
budget authority having the power to decide whether to go on \\
with the project, not the PPP unit)
\end{tabular}

Source: OECD (2012), Recommendation of the Council on Principles for Public Governance of Public-Private Partnerships www.oecd.org/governance/budgeting/PPP-Recommendation.pdf

\footnotetext{
${ }^{23}$ http://www.oecd.org/gov/budgeting/oecd-principles-for-public-governance-of-public-private-partnerships.htm

${ }^{24}$ The results of a 2010 OECD questionnaire presented in Burger and Hawkesworth (2011) provides very useful information about different country practices in PPP governance with or without established PPP units.

${ }^{25}$ There are different definitions of the concept "value for money" in the literature; OECD Principles (2012) defines it as "the optimal combination of quality, features and price, calculated over the whole of the project's life.

${ }^{26}$ A recent World Bank study by Aslan and Duarte (2014) refers to this authority as "Financial authority" with the same roles assigned.
} 


\section{Implications for public debt management}

From a public debt manager's perspective, explicit PPP guarantees of various forms listed above are not different from the government credit guarantees discussed in the previous section, in terms of their relationship with and potential impacts on public debt and central government budget. However, the OECD Survey results indicate that public debt managers are much less involved in the management of PPP guarantees than they are with the credit guarantees. Among the 18 countries that responded to the question "Is the DMO responsible in the management of the PPP explicit contingent liabilities at any level?" only Turkey responded "Yes". This distance observed in practice between the PPP contingent liabilities and public debt managers is difficult to justify. Indeed, there is policy areas in which the debt managers might be effectively involved.

The PPP decision as a model of procurement should be based on a value for money analysis, implying that the PPP choice should be proven superior to the traditional procurement model from the public party's perspective. Although quantitative value for money analysis might have differences in methodology ${ }^{27}$, it is essential to include the estimated fiscal costs of the project into the calculations. This exercise involves taking into account of the PPP guarantees from the very beginning, as these guarantees change the risk sharing between the public and the private parties. Thus, guarantee valuation should be considered as a critical component of the PPP decision-making. On the other hand, value for money analysis should not only be conducted ex-ante but also ex-post, in order to ensure that it is maintained throughout the life of the project.

Given this framework, Table 10 includes suggestions for the public debt managers' possible involvement into the PPP processes. The roles suggested might not be relevant for DMOs of some countries in which case it is highly recommended to have another central government institution performing the listed functions for better management of fiscal risks arising from PPPs. Indeed, the interventions suggested for the public debt managers in the below table can be considered as complementing the role to be played by the "central budget authority" in the OECD Principles. Public debt manager's risk management and mitigation abilities might well complement budget authority's perspective of fiscal affordability. In jurisdictions where specialized PPP units exist, their role should be considered as complementing that of procuring institutions, rather than the central budget authority.

\footnotetext{
${ }^{27}$ See World Bank (2013) and Burger and Hawkesworth (2011) for detailed information on value for money and country practices.
} 


\section{Before the PPP decision is made (during the planning and feasibility stages)}

\begin{tabular}{|c|c|}
\hline $\begin{array}{l}\text { guarantees provided by the procuring } \\
\text { institutions } \\
\text { (first level of commitments) }\end{array}$ & $\begin{array}{l}\text { guarantees provided by the ministry of } \\
\text { finance/treasury } \\
\text { (second level of commitments) }\end{array}$ \\
\hline $\begin{array}{l}\text { consultative and advisory services about; } \\
\text { - level, conditions and terms of } \\
\text { proposed guarantees } \\
\text { valuation of the guarantees to be } \\
\text { provided, which is necessary for } \\
\text { making the project's value for } \\
\text { money assessment } \\
\text { pricing of the guarantees, if a fee is } \\
\text { to be charged }\end{array}$ & $\begin{array}{l}\text { active involvement in; } \\
\text { - decision-making or informing the } \\
\text { decision-making authority about the } \\
\text { level, conditions and terms of proposed } \\
\text { guarantees } \\
\text { - valuation of the guarantees to be } \\
\text { provided, which is necessary for making } \\
\text { the project's value for money } \\
\text { assessment } \\
\text { - pricing of the guarantees, if a fee is to } \\
\text { be charged } \\
\text { - preparation and negotiation of } \\
\text { contractual clauses on the guarantees }\end{array}$ \\
\hline
\end{tabular}

After the signature of the PPP contract

(throughout the life of the PPP)

\begin{tabular}{|c|c|}
\hline $\begin{array}{c}\text { guarantees provided by the procuring } \\
\text { institutions } \\
\text { (first level of commitments) }\end{array}$ & $\begin{array}{l}\text { guarantees provided by the ministry of } \\
\text { finance/treasury } \\
\text { (second level of commitments) }\end{array}$ \\
\hline $\begin{array}{l}\text { monitoring; } \\
\text { - payments and collections from the } \\
\text { existing guarantees } \\
\text { - periodic valuation of the guarantees } \\
\text { already provided, which is necessary } \\
\text { for establishing if the project's value } \\
\text { for money is maintained } \\
\text { - any major changes in project's risks } \\
\text { that might have impact on the } \\
\text { existing guarantees }\end{array}$ & $\begin{array}{l}\text { active involvement in; } \\
\text { - recording and budgeting of the payments } \\
\text { and collections from the existing } \\
\text { guarantees in line with international } \\
\text { standards and best practices } \\
\text { periodic valuation of the guarantees } \\
\text { already provided, which is necessary for } \\
\text { establishing if the project's value for } \\
\text { money is maintained } \\
\text { monitoring any major changes in } \\
\text { project's risks that might have impact on } \\
\text { the existing guarantees } \\
\text { disclosing qualitative and quantitative } \\
\text { information on the guarantees through } \\
\text { debt management reports and/or } \\
\text { budgetary documentation }\end{array}$ \\
\hline
\end{tabular}


Regardless of the issuer institution of the PPP guarantees, the effective management and mitigation of fiscal risks arising from the existing PPP portfolio calls for the following functions to be performed by the related government units:

- undertaking scenario analysis and stress tests

- providing estimates of expected and maximum losses from the portfolio to analyse fiscal sustainability of central government over medium to long term

- providing estimates of expected and maximum losses from the portfolio to analyse debt sustainability of central government over medium to long term

- applying ceilings on contingent liabilities from PPPs to promote fiscal discipline.

\section{Transparency}

Transparency of contingent liabilities increases the likelihood that these liabilities are taken on for sound reasons and it helps eliminate the bias toward them. Transparency is particularly important in the framework of PPPs, as the governments might be inclined more towards the PPPs if the costs and risks are managed in a non-transparent way.

Raising the awareness of the long-term fiscal impact of PPPs is important for governments and they can disclose information on PPPs regardless of the complexity of their budgetary, accounting, and statistical standards. This information could include supplementary statistics that provide medium- and long-term forecasts of PPP spending and revenue, descriptions of the contracts and their fiscal costs and risks, and the contracts themselves (Funke, $\mathrm{K}$ et al., 2013). Contingent liabilities under PPPs, in this context, are among the critical information to be disclosed as major source of fiscal risk.

DMOs can work together with the central budget authority in data consolidation, forecasting and reporting practices on the PPP contingent liabilities; or include this information in their debt reporting. The degree of the public debt managers' involvement in disclosure is a function of the PPP legislative frameworks in countries, which determine their access to the related data.

\subsection{Government sponsored insurance programmes}

Government insurance programmes are another major source of explicit contingent liabilities. They are special programmes providing insurance coverage for low frequency but high impact events like bank failures, floods, earthquakes, terrorist activities, etc., where the form and amount of government support or intervention are pre-described explicitly by law. Not surprisingly, these insurance programme areas coincide with the sources of large implicit contingent liabilities for governments; financial system, terrorist activities, catastrophic events and environmental disasters. In other words, government sponsored insurance programmes should be considered as ex ante financial measures aimed at increasing governments' readiness for and protection against losses expected from certain disastrous events.

In some insurance schemes, government plays directly the role of an insurance provider (selfinsurance) while in others it might choose to purchase insurance from the private insurance companies (market insurance). In the latter case, the event risk is transferred to the private sector while the risk premiums are paid out of the government budget without creating any explicit contingent liability but direct commitments. However, there are various different forms of government insurance schemes falling between self-insurance and market insurance, depending on the source of risk, availability of market for providing insurance against this risk and the policy objectives of the government. 


\section{Government deposit insurance}

Government deposit insurance is one of the most important and widely applied mechanisms in this category ${ }^{28,29}$. Major purposes of the deposit insurance systems are, to offer consumer protection and to reduce the risks of bank runs in case of banking failures, runs that can trigger systemic crises.

Table 11 summarizes the main characteristics of deposit insurance systems in the OECD countries based on the database provided by Demirgüç-Kunt et al. (2014). In almost all of the OECD countries, there exist explicit deposit insurance systems (the exceptions are Israel and New Zealand). In terms of the administration of the deposit insurance system, the common practice is to have a separate legal entity. This entity is administered publicly, privately or jointly in different country cases. The funding source of the system is private in most of the OECD countries; the exceptions being Australia and Chile which have government funded insurance systems and in Portugal where the system is funded jointly between the public and private sources. In most OECD countries, deposit insurance systems are run through a fund into which the premiums paid by the banks are pooled ex ante (there are several countries with ex post structures). In other words, the deposit insurance system is financed by the banks themselves ${ }^{30}$.

The insurance coverage provided might be limited based on deposit types, amounts or eligible institutions or unlimited covering all the deposits within the banking system. In some cases, the insurance coverage is set to be unlimited temporarily, as was the case in some OECD countries during the global crisis. Governments sometimes envisage in legislation some contingency plans even if the source of funding in the deposit insurance system is not government, considering the possibility that the deposit fund reserves available might fall short during the times of bank failures. This "backstop" might take the form of pre-approved credit lines from the Treasury, or the institution managing the deposit fund might issue bonds or receive loans guaranteed by the government.

\footnotetext{
${ }^{28}$ Some authors classify deposit insurance among financial guarantees rather than under insurance schemes, considering that these are guarantees covering banks' payment obligations towards their depositors in case of bank failure.

${ }^{29}$ In Annex A, deposit insurance systems of Turkey, South Africa, Mexico and Sweden are explained in detail.

${ }^{30}$ For detailed information about deposit insurance systems in different countries see Demirgüç-Kunt et al. (2014).
} 
Table 10. Deposit insurance systems in the OECD countries

\begin{tabular}{|c|c|c|c|c|c|c|}
\hline Country & $\begin{array}{l}\text { Nature of } \\
\text { the system }\end{array}$ & $\begin{array}{l}\text { Fund } \\
\text { structure }\end{array}$ & $\begin{array}{l}\text { Explicit } \\
\text { contingency } \\
\text { plan }^{(*)}\end{array}$ & Fund source & $\begin{array}{l}\text { Fund } \\
\text { administration }\end{array}$ & $\begin{array}{l}\text { Fund } \\
\text { organisation }\end{array}$ \\
\hline Australia & explicit & ex post & yes & government & public & $\begin{array}{l}\text { central bank/ } \\
\text { ministry }\end{array}$ \\
\hline Austria & explicit & ex post & yes & private & private & legally separate \\
\hline Belgium & explicit & ex ante & yes & private & joint & legally separate \\
\hline Canada & explicit & ex ante & & private & public & legally separate \\
\hline Chile & explicit & ex post & & government & public & \\
\hline Czech Republic & explicit & ex ante & & private & joint & legally separate \\
\hline Denmark & explicit & ex ante & yes & private & joint & legally separate \\
\hline Estonia & explicit & ex ante & yes & private & joint & legally separate \\
\hline Finland & explicit & ex ante & & private & private & legally separate \\
\hline France & explicit & ex ante & & private & joint & legally separate \\
\hline Germany & explicit & ex ante & & private & joint & legally separate \\
\hline Greece & explicit & ex ante & & private & joint & legally separate \\
\hline Hungary & explicit & ex ante & yes & private & joint & legally separate \\
\hline Iceland & explicit & ex ante & & private & joint & $\begin{array}{l}\text { central } \\
\text { bank/ministry }\end{array}$ \\
\hline Ireland & explicit & ex ante & yes & private & public & legally separate \\
\hline Israel & implicit & & & & & \\
\hline Italy & explicit & ex post & & private & private & legally separate \\
\hline Japan & explicit & ex ante & & private & joint & legally separate \\
\hline Korea & explicit & ex ante & & private & public & legally separate \\
\hline Luxembourg & explicit & ex post & & private & private & legally separate \\
\hline $\operatorname{Mexico}(* *)$ & explicit & ex ante & yes & private & public & legally separate \\
\hline Netherlands & explicit & ex post & & private & public & $\begin{array}{l}\text { central } \\
\text { bank/ministry }\end{array}$ \\
\hline New Zealand & implicit & & & & & \\
\hline Norway & explicit & ex ante & & private & private & legally separate \\
\hline Poland & explicit & ex ante & & private & public & legally separate \\
\hline
\end{tabular}




\begin{tabular}{lllllll}
\hline Country & $\begin{array}{l}\text { Nature of } \\
\text { the system }\end{array}$ & $\begin{array}{l}\text { Fund } \\
\text { structure }\end{array}$ & $\begin{array}{l}\text { Explicit } \\
\text { contingency } \\
\left.\text { plan }{ }^{*}\right)\end{array}$ & Fund source & $\begin{array}{c}\text { Fund } \\
\text { idministration }\end{array}$ & $\begin{array}{l}\text { Fund } \\
\text { organisation }\end{array}$ \\
\hline Portugal & explicit & ex ante & yes & joint & public & legally separate \\
\hline Slovak Republic & explicit & ex ante & yes & private & joint & legally separate \\
\hline Slovenia & explicit & ex post & yes & private & private & $\begin{array}{l}\text { central } \\
\text { bank/ministry }\end{array}$ \\
\hline Spain & explicit & ex ante & & private & private & legally separate \\
\hline Sweden $(* * *)$ & explicit & ex ante & & private & public & $\begin{array}{l}\text { central } \\
\text { bank/ministry }\end{array}$ \\
\hline Switzerland & explicit & ex post & & private & private & legally separate \\
\hline Turkey & explicit & ex ante & yes & private & public & legally separate \\
\hline United Kingdom & explicit & ex post & yes & private & public & legally separate \\
\hline United States & explicit & ex ante & yes & private & public & legally separate \\
\hline
\end{tabular}

${ }^{(*)}$ Legislation stipulates that in case of a shortfall of funds to cover the deposits insured, deposit insurance organisation can issue bonds or receive loans guaranteed by government or may access to funding from the central bank or ministry of finance.

${ }^{(* *)}$ For Mexico and Turkey, the source of information on the existence of contingency plans is this study.

${ }^{(* * *)}$ The SNDO is responsible from the management of the deposit insurance system.

Source: Adapted from Demirgüç-Kunt, A. et al. (2014), Deposit Insurance Database.

https://www.imf.org/external/pubs/ft/wp/2014/wp14118.pdf

\section{Implications for public debt management}

The ability and credibility of governments, especially of the ones with relatively less fiscal space, in meeting their promises under the deposit insurance systems is an issue, because the maximum exposure loss (cash flow at risk) is relatively high considering the level of covered deposits within the financial system. Country experiences suggest that during systemic banking crisis, deposit insurance fund resources coming from the banks themselves usually fall short of the arising funding needs, compelling governments to deploy central government resources and debt financing, mostly in the form of bond issuances by DMOs or by the deposit insurance institutions, which are backed (guaranteed) by the central government.

The fiscal costs of systemic banking crisis might be so high that it takes years of collaboration between the debt management offices and the deposit insurance institution to pay out or roll over the related financial liabilities. In this regard, Mexico is a good example: the 1995 crisis left the deposit insurance institution (IPAB) with a stock of liabilities funded from the markets through bond issuances guaranteed by the Mexican Congress. The fiscal burden of the Tequila crisis still continues and necessitates coordination between the DMO and the IPAB in the bond markets 20 years after the crisis. Turkey is yet another example of such an experience in which case it took almost 10 years to redeem the securities issued to back the deposit insurance system.

The involvement by the public debt managers in this governance area is rather limited given the special expertise and mandate required for their management. In the survey results among the 18 
DMOs who responded, it is only the SNDO having a mandate in the management of government deposit insurance programmes. On the other hand, the SNDO performs this function separately from its PDM functions. However, public debt managers can work with deposit insurance manager institution and financial system regulators in the field of contingent liabilities under deposit insurance systems to promote strategic risk taking and risk mitigation. In this context, the following key policies can be suggested:

- clear legislative frameworks defining the scope and nature of government's role within the system - as insurer/guarantor/liquidity provider

- effective reserve management (in ex ante fund structures) with risk based premium systems

- effective and regular coordination and consultation with deposit insurance managers and financial system regulators over the fiscal risks arising from the financial system.

Other insurance programmes in which governments are involved are mainly disaster risk insurance programmes designed for losses from catastrophic events and natural disasters ${ }^{31}$. During the last decades, the incidence of catastrophic events, especially those related with climate has increased steadily causing large fiscal costs for governments. In parallel with this increase, governments' involvement in the catastrophe risk insurance programmes, especially in developed countries, has amplified.

In several countries, governments are involved in insurance programmes mainly due to lack of insurance coverage in the private market or unavailability of affordable insurance for the related segments of the society. Governments that experienced large-scale catastrophes with high disaster relief costs in the past are also more prone to design insurance frameworks.

Insurance programmes are one of the instruments providing ex ante financing solutions for governments in disaster risk management. Other ex-ante financial sources are budget contingencies, reserve funds, contingent debt facilities and catastrophe bonds; while ex-post sources include donor assistance, budgetary reallocations, domestic and external credits and tax incomes.

Governments need to analyse their risk bearing capacity before engaging in such insurance programmes. This analysis includes assessments of government's fiscal position, budgetary flexibility, public debt sustainability, as well as the ability to have access to financing resources in the post disaster conditions. This exercise is combined with the technical assessment of the probability of event occurring. If the disaster risk is minor and the risk bearing capacity is high, ex post solutions would be more rational for some governments (G20/OECD, 2012) ${ }^{32}$.

When the insurance is deemed necessary, governments can get involved in this process in various ways. The appropriate role for the government would depend on the programme features, policy objectives, and the extent to which the government plans to assume the costs of the disaster risk covered.

\footnotetext{
${ }^{31}$ Another important area is "Terrorism Risk Insurance", for information on OECD governments' involvement in terrorism risk insurance programmes see http://www.oecd.org/daf/fin/insurance/Terrorism-RiskInsurance-Country-Comparison\%207\%20april\%202015.pdf

${ }^{32}$ Disaster Deficit Index (DDI) produced by the Inter-American Development Bank is a useful tool to measure the financial vulnerability of governments against natural disasters. For details see http://www.iadb.org/exr/disaster/ddi.cfm?language=EN\&parid=2
} 
Table 11. Roles of government in disaster insurance schemes and country examples*

\section{Backstop liquidity provider}

United Kingdom (Pool Re)

\section{Reinsurer}

Australia (Australian Reinsurance Pool Corporation or ARPC)

Belgium (Caisse nationale des calamites + participation in Terrorism Reinsurance and Insurance Pool)

Denmark (participation in Terrorism Insurance Pool for Non-Life Insurance)

France (Caisse Centrale de Réassurance or CCR)

Japan (Japan Earthquake Reinsurance Co., Ltd. or JER)

Germany (participation in Extremus AG)

Netherlands (participation in Nederlandse Herverzekeringsmaatschappij voor

Terrorismeschaden or NHT)

United States (participation in Terrorism Risk Insurance Programme)

\section{Direct Insurer}

Iceland (Iceland Catastrophe Insurance or ICI)

New Zealand (Earthquake Commission or EQC)

South Africa (SASRIA Limited)

Spain (Consorcio de compensacion de seguros)

Turkey (Turkish Catastrophe Insurance Pool)

United States (California Earthquake Authority, National Flood Insurance Programme or NFIP)

\section{Guarantor}

Australia (Australian Reinsurance Pool Corporation or ARPC)

Denmark (Storm surge - Danish Storm Council)

France (Caisse Centrale de Réassurance or CCR)

New Zealand (Earthquake Commission or EQC)

Spain (Consorcio de compensacion de seguros)

United States (National Flood Insurance Programme or NFIP)

* Backstop liquidity provider: The government provides liquidity, through a pre-arranged loan facility, to insurers to relieve funding pressures and enable them to make payments on a potentially large number of claims linked to a catastrophic event".

"Reinsurer: The government or a special entity established by the government assumes some or all of the liabilities assumed by insurers in connection with disaster risks, and then possibly cedes some or all these risks to global reinsurance markets".

"Direct insurer: Alternatively, the government or a special entity established by the government in some countries directly provides disaster insurance".

"Guarantor: Where institutional arrangements exist, governments often explicitly guarantee some or all of the liabilities assumed in connection with disaster risks" G20/OECD (2012).

Source: OECD/G20 (2012), Disaster Risk Assessment and Risk Financing, A G20/OECD Methodological Framework, www.oecd.org/gov/risk/G20disasterriskmanagement.pdf 
In the case of self-insurance (direct insurer) solutions, public reserve fund applications are quite common practice, which are similar to contingency reserve funds discussed under the government credit guarantees section. National Calamity Fund in Colombia, Environmental Contingency Fund of U.S., and Natural Disaster Fund in Mexico are yet several examples of many. Although they are regarded as useful risk mitigation tools, as in the case of actual funds for credit guarantees, there is a cost attached to holding a cash fund with the expectation of a future natural disaster.

Governments are also involved in insurance programmes by explicitly guaranteeing a part of the liabilities to occur under the programme. These guarantees usually take the form of backstop arrangements under deposit insurance, or guarantees provided under PPPs, in the sense that they are forms of risk sharing with the private sector while increasing the credibility of the system in covering the anticipated future losses. There might be a layered approach with private insurers or funds, i.e. damages are covered by the market until a certain threshold amount for the government guarantee to be called.

\section{Implications for public debt management}

The G20/OECD Methodological Framework for Disaster Risk Assessment and Risk Financing (2012) explains the appropriate role of finance ministries in disaster risk management and financing frameworks as: "Finance Ministries have a key role in ensuring an effective approach to the financial management of disaster risks - promoting the role of risk financing markets where feasible, ensuring the proper design of any market interventions, considering the development of public financial aid arrangements and programmes as a complement to any private compensation mechanisms and engaging in sound fiscal management of government contingent liabilities. Being centrally placed to affect the financial sector, budget making and the provision of financial guarantees, Finance Ministries have the responsibility to ensure that financial strategies for DRM are well integrated, efficient and effective. At a time when many countries are facing severe financial constraints, identifying the source of potential contingent liabilities and providing ex ante frameworks for managing them contributes to more robust public finances in the long term. Finance Ministries also have an important stake in ensuring the quality and policy relevance of country risk assessments and strengthening their own input into the risk assessment process as a means to ensure the development of cost-effective DRM strategies and financial strategies".

Following from this framework policy recommendations, contingent liabilities arising from government insurance programmes are among the areas where centralised fiscal risk management function of the government would be useful. As part of this function, public debt managers can be consulted in developing financing strategies and guarantees under these programmes, including the stage where the need for such ex ante programmes are assessed. From the perspective of public debt managers, government insurance as an ex ante source of risk financing would seem preferable over $e x$ post search for funds when the disasters are realised. However, this preference might not be that straightforward as country specific and programme specific cost-risk analysis might prove ex-post solutions less costly. Thus, analyses involving finance ministries and DMOs are highly recommended before enrolling governments in these programmes with direct and contingent fiscal commitments by the governments. 


\section{PART 3. SUMMARY OF POLICY CONCLUSIONS AND RECOMMENDATIONS}

\section{Policy conclusions and recommendations}

This paper examines the role of public debt managers in the following three categories of contingent liabilities and included several recommendations under each section. Although intended for the public debt managers, in countries where DMOs do not have any roles and responsibilities in fiscal risk management in general and contingent liability management in particular these recommendations might be relevant for other government units.

\section{Government credit guarantees}

This study included examples from the implementation frameworks showing that the DMOs are involved in the management of government credit guarantees at different stages including the assessment of guarantee proposals, contract design and the risk management of the credit guarantee portfolio. The main recommendations of this study are the following:

- Costs and risks of the credit guarantee should be calculated to inform the decision-making authorities accordingly.

- Programme loan guarantees should have clearly-stated objectives and a set of rules or a code of conduct for granting.

- Fees corresponding to at least the expected cost of each guarantee should be charged from the beneficiaries.

- The terms of the credit guarantee contracts should be drafted in a way as to clearly define and limit the guarantee in time and scope.

- A ceiling on the stock or new issuances of credit guarantees might be helpful to promote fiscal discipline, limit the fiscal risk exposure and direct the policy-makers towards prioritisation among the applications.

- Contingency reserve funds, whether actual or notional, is a useful tool to increase the governments' ability to cover possible future losses and monitor their financial position vis-àvis the existing guarantees.

- Both quantitative and qualitative information on credit guarantees should be disclosed based on their expected cost and in such a way as to give a complete picture of the government's total financial position, both as part of debt management reporting and budgetary documentation.

\section{Contingent liabilities arising from PPPs}

The country practices in the area of PPP contingent liabilities revealed that DMOs are generally not involved in their management. However, based on the OECD/G20 recommendations for effective 
PPP governance, certain functions to be performed by the central government units were discussed. In this context, this study recommends that public debt managers can well work together with other government units in the field of PPP guarantees. The main recommendations in this area are the following:

- The PPP fiscal risks can be mitigated through strengthening the regulatory frameworks, strengthening the management and oversight frameworks, increasing transparency and integrating PPPs into the medium term budget process (IMF, 2014).

- As is the case for the government credit guarantees, a central government unit should analyse the PPP guarantees to inform the decision-making authorities on the associated costs and risks.

- Guarantee valuation should be considered as a critical component of the PPP decision making since the guarantees change the risk allocation between the public and the private partner.

- Contingent liabilities under the PPP contracts should be centrally monitored at the central government level for the purpose of ensuring fiscal and debt sustainability.

- DMOs can work together with the central budget authority and the PPP units in data consolidation, forecasting and reporting practices on the PPP contingent liabilities; or include this information in their debt reporting.

\section{Government sponsored insurance schemes}

Government deposit insurance systems and other government sponsored insurance programmes were discussed with examples from countries. The study showed that these insurance programmes comprise explicit contingent commitments on the side of governments. The degree of the DMOs' involvement in these special expertise areas was also quite low, based on the survey results. However, the following recommendations for the public debt managers were provided:

- Stability in the financial markets is crucial for public debt managers and a healthy banking system that runs with effective prudential regulations, and supervision, with a credible and well managed deposit insurance framework would contribute to this end.

- Public debt managers are recommended to be well informed of the contingent liabilities under the government sponsored insurance systems.

- Clear legislative frameworks defining the scope and nature of government's role within the insurance programmes are recommended.

- Regular coordination between deposit and other insurance managers and public debt managers over the fiscal risks arising from the financial system are considered useful.

- Analyses involving finance ministries and DMOs are highly recommended before enrolling governments in the insurance programmes with direct and contingent fiscal commitments. 


\section{REFERENCES}

Aslan, C. and D. Duarte (2014), "How Do Countries Measure, Manage, and Monitor Fiscal Risks Generated by Public-Private Partnerships? Chile, Peru, South Africa, Turkey", Policy Research Working Paper 7041, September 2014, http://documents.worldbank.org/curated/en/ 485861468307741430/pdf/WPS7041.pdf

Blommestein, H., V. Guzzo, A. Holland and Y. Mu (2010), "Debt Markets: Policy Challenges in the Post-Crisis Landscape", OECD Journal: Financial Market Trends, Vol. 2010/1, DOI: http://dx.doi.org/10.1787/fmt-2010-5km7k9tp0tf3

Burger, P, J. Tyson, I. Karpowicz, and M.D. Coelho (2009), "The Effects of the Financial Crisis on Public-Private Partnerships”, IMF Working Paper, WP/09/144, https://www.imf.org/external/ pubs/ft/wp/2009/wp09144.pdf

Burger, P and I. Hawkesworth, (2011), "How to Attain Value for Money: Comparing PPP and Traditional Infrastructure Public Procurement”, OECD Journal on Budgeting, Volume 2011/1, www.oecd.org/gov/budgeting/49070709.pdf

Cebotari, A. (2008), "Contingent Liabilities: Issues and Practice”, IMF Working Paper, WP/08/245, www.imf.org/external/pubs/ft/wp/2008/wp08245.pdf

Cebotari, A, J. Davis, L. Lusinyan, A. Mati, P. Mauro, M. Petrie and R. Velloso (2009), "Fiscal Risks: Sources, Disclosure, and Management", IMF, 2009.

Demirgüç-Kunt, A., E. Kane, and L. Laeven (2014), "Deposit Insurance Database", June 2014, IMF Working Paper, www.imf.org/external/pubs/ft/wp/2014/wp14118.pdf

EPEC (2010a), "Eurostat Treatment of Public Private Partnerships, Purposes, Methodology and Recent Trends", http://ppp.worldbank.org/public-private-partnership/sites/ppp.worldbank.org/ files/documents/Eurostat\%20Treatment\%20of\%20PPP.pdf

EPEC (2010b), “Capital markets in PPP financing: Where we were and where are we going?", March 2010, http://www.eib.org/epec/resources/epec-capital-markets.pdf

EPEC (2011), "State Guarantees in PPPs: A Guide to Better Evaluation, Design, Implementation and Management", http://ec.europa.eu/eurostat/web/government-finance-statistics/data/database

EPEC (2015), Market Update, Review of the European PPP Market 2015, http://www.eib.org/epec/library/epec market update 2015 en2

European Commission, International Monetary Fund, Organization for Economic Cooperation and Development, United Nations, World Bank (2008), "System of National Accounts", New York, http://unstats.un.org/unsd/nationalaccount/docs/SNA2008.pdf 
Eurostat (2010), "European System of Accounts (ESA) 2010”, http://ec.europa.eu/eurostat/documents/ 3859598/5925693/KS-02-13-269-EN.PDF/44cd9d01 bc64-40e5-bd40-d17df0c69334

Eurostat (2015), "Supplementary Table for the Financial Crisis - Background note" (April 2015), http://ec.europa.eu/eurostat/documents/1015035/2022710/Background-note-fin-crisis-OCT-2015final.pdf

Grande, G., A. Levy, F. Panetta, and A. Zaghini (2011), "Public Guarantees on Bank Bonds: Effectiveness and Distortions", OECD Journal: Financial Market Trends, Vol. 2011/2, Paris. www.oecd.org/finance/financial-markets/49200208.pdf

IMF (2012), "Fiscal Transparency, Accountability, and Risk", prepared by the Fiscal Affairs Department in collaboration with the Statistics Department, International Monetary Fund, www.imf.org/external/np/pp/eng/2012/080712.pdf

IMF (2014), "Fiscal Monitor", April 2014, International Monetary Fund, www.imf.org/external/ pubs/ft/fm/2014/01/fmindex.htm

Inter-American Development Bank, “Disaster Deficit Index”, www.iadb.org/exr/disaster/idea_ddi.pdf

Levy, A. and S. Schich, (2010), "The design of government guarantees for bank bonds: Lessons from the recent financial crisis", OECD Journal: Financial Market Trends, Vol. 2010, Issue 1, Paris, www.oecd.org/daf/fin/financial-markets/45636972.pdf

Levy, A and A. Zaghini (2011), "The pricing of government-guaranteed bank bonds, Banks and Bank Systems", Volume 6, Issue 3, http://businessperspectives.org/journals free/bbs/2011/ BBS_en_2011_03_Levy.pdf

Lindwall, P. (2013), "Budgeting for Contingent Liabilities”, Discussion Paper for 34th Annual Meeting of OECD Senior Budget Officials, https://one.oecd.org/document/GOV/PGC/SBO(2013)7/en/pdf

OECD (2002), "Best Practices for Budget Transparency", OECD, www.oecd.org/gov/budgeting/Best\%20Practices\%20Budget\%20Transparency\%20\%20complete\%20with\%20cover\%20page.pdf

OECD (2005) “Advances in Risk Management of Government Debt”, OECD Publishing, Paris. DOI: http://dx.doi.org/10.1787/9789264104433-en

OECD (2009), The Impact of the Global Crisis on SME and Entrepreneurship Financing and Policy Responses, OECD Publishing, Paris, https://www.oecd.org/cfe/smes/43183090.pdf

OECD (2011), "Financial Crisis Management and the Use of Government Guarantees", Collection of papers prepared for an OECD-hosted Symposium held in October 2011 and published as a special issue of OECD Journal: Financial Market Trends, Paris, Error! Hyperlink reference not valid..

OECD (2012), "Recommendation of the Council on Principles for Public Governance of PublicPrivate Partnerships", www.oecd.org/governance/budgeting/PPP-Recommendation.pdf

OECD (2013), Financing SMEs and Entrepreneurs, An OECD Scoreboard, OECD, Paris, DOI http://dx.doi.org/10.1787/fin sme ent-2013-en 
OECD (2014), Sovereign Borrowing Outlook, OECD Publishing, Paris, DOI: http://dx.doi.org/10.1787/sov_b_outlk-2014-en

OECD (2016), Sovereign Borrowing Outlook, OECD Publishing, Paris, DOI: http://dx.doi.org/10.1787/sov b outlk-2016-en

OECD, Financial Sector Guarantees, www.oecd.org/finance/financialsectorguarantees.htm

OECD, International Platform on Terrorism Risk Insurance, National Terrorism Risk Insurance Programmes of OECD Countries with Government Participation www.oecd.org/daf/fin/insurance/ Terrorism-Risk-Insurance-Country-Comparison.pdf

OECD/G20 (2012), "Disaster Risk Assessment and Risk Financing”, A G20/OECD Methodological Framework www.oecd.org/gov/risk/G20disasterriskmanagement.pdf

Schich, S. and K. Byoung-Hwan (2011), "Guarantee Arrangements for Financial Promises: How Widely Should the Safety Net be Cast?”, OECD Journal: Financial Market Trends, Vol. 2011/1 www.oecd.org/daf/fin/financial-markets/48297609.pdf 


\section{WORKING PAPERS PUBLISHED TO DATE}

This list shows all OECD Working Papers on Sovereign Borrowing and Public Debt Management published to date. They are available online at http://oe.cd/pdmwp.

WP7: Assessing the cost effectiveness of index-linked bond issuance - A methodological approach, illustrated using UK examples (2013)

WP6: An overview of leading practices in investor relations and communications in the OECD Area (2013)

WP5: Buyback and exchange operations: Policies, procedures and practices among OECD Public Debt Managers (2012)

WP4: A Critical Analysis of the Technical Assumptions of the Standard Micro Portfolio Approach to Sovereign Debt Management (2012)

WP3: Interactions between sovereign debt management and monetary policy under fiscal dominance and financial instability (2012)

WP2: Principles and trade-offs when making issuance choices in the UK (2011)

WP1: Regulatory reform of OTC derivatives and its implications for sovereign debt management practices (2011) 